DIW BERLIN

Discussion

Papers

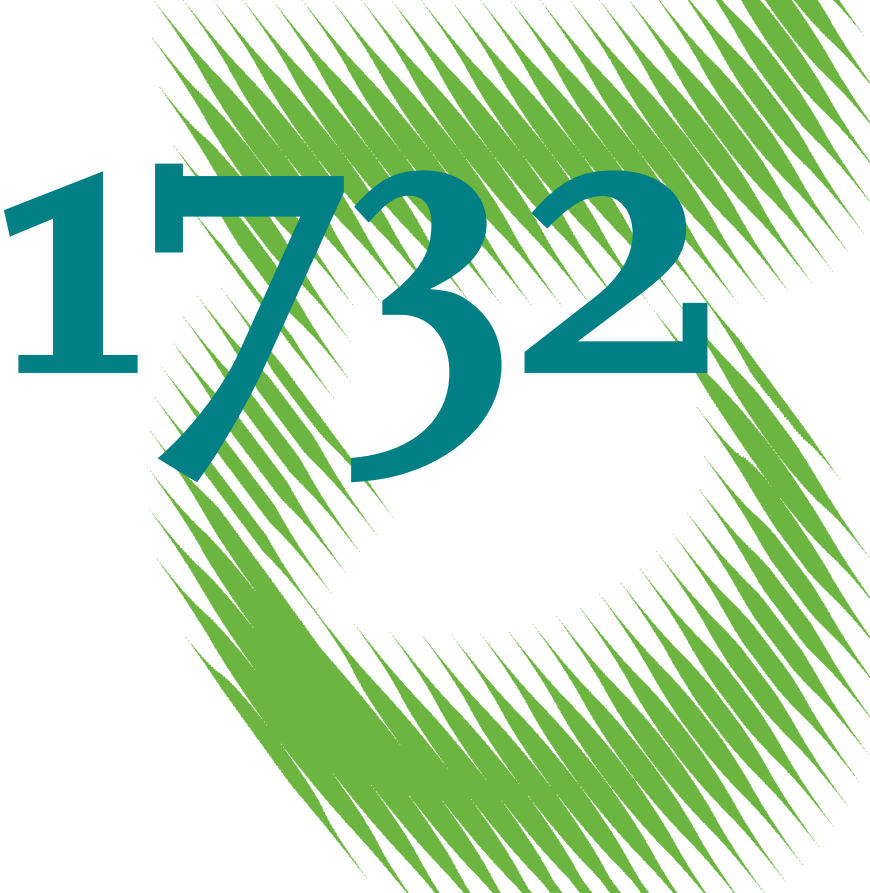

Business Cycles and Start-Ups across Industries: An Empirical Analysis of German Regions 
Opinions expressed in this paper are those of the author(s) and do not necessarily reflect views of the institute.

IMPRESSUM

(C) DIW Berlin, 2018

DIW Berlin

German Institute for Economic Research

Mohrenstr. 58

10117 Berlin

Tel. +49 (30) $89789-0$

Fax +49 (30) $89789-200$

http://www.diw.de

ISSN electronic edition 1619-4535

Papers can be downloaded free of charge from the DIW Berlin website:

http://www.diw.de/discussionpapers

Discussion Papers of DIW Berlin are indexed in RePEc and SSRN:

http://ideas.repec.org/s/diw/diwwpp.html

http://www.ssrn.com/link/DIW-Berlin-German-Inst-Econ-Res.html 


\title{
Business Cycles and Start-Ups across Industries: An Empirical Analysis of German Regions ${ }^{1}$
}

\author{
Alexander Konon, ${ }^{2}$ Michael Fritsch, ${ }^{3}$ Alexander Kritikos ${ }^{4}$
}

\begin{abstract}
We analyze whether start-up rates in different industries systematically change with business cycle variables. Using a unique data set at the industry level, we mostly find correlations that are consistent with counter-cyclical influences of the business cycle on entries in both innovative and non-innovative industries. Entries into the largescale industries, including the innovative part of manufacturing, are only influenced by changes in the cyclical component of unemployment, while entries into small-scale industries, like knowledge intensive services, are mostly influenced by changes in the cyclical component of GDP. Thus, our analysis suggests that favorable conditions in terms of high GDP might not be germane for start-ups. Given that both innovative and non-innovative businesses react counter-cyclically in 'regular' recessions, business formation may have a stabilizing effect on the economy.
\end{abstract}

JEL classification: E32, L16, L26, R11

Keywords: $\quad$ New business formation, entrepreneurship, business cycle, manufacturing, services, innovative industries

\footnotetext{
${ }^{1}$ We are indebted to Sandra Kublina, Katharina Pijnenburg, and Michael Wyrwich for support in preparing the data and to David Audretsch, Werner Bönte, Christian Dreger, Adam Lederer, Helmut Lütkepohl, Dieter Nautz, Simon Parker, Benjamin Schäfer, and Roy Thurik as well as to the participants at the SEEK Workshop in Brussels, the Research Symposium "Entrepreneurship, Local Policies and Regional Economic Development" in the University of Siegen, the Workshop "Entrepreneurship and Reigniting Growth in the EU" in Berlin, the 16th Conference on Research on Economic Theory and Econometrics in Milos, and the Entrepreneurship Residence Week in Oxford for comments that helped us improve this paper.

${ }^{2}$ Alexander Konon is Doctoral Student at the German Institute for Economic Research (DIW Berlin). akonon@diw.de

${ }^{3}$ Michael Fritsch is Chair of Business Dynamics, Innovation, and Economic Change at the Friedrich Schiller University Jena, and Research Professor at the Halle Institute for Economic Research (IWH). m.fritsch@uni-jena.de

${ }^{4}$ Alexander Kritikos (Corresponding Author) is Research Director at the German Institute for Economic Research (DIW Berlin), Professor of Economics at the University of Potsdam, and Research Fellow of the IZA, Bonn and of the IAB, Nuremberg. akritikos@diw.de
} 


\section{Introduction}

Research postulates that the cyclical changes of macroeconomic factors, such as the business cycle and unemployment, influence the number of new firms (Parker 2012a; Köllinger and Thurik 2012). Theoretical considerations suggest that these two variables may unfold either pro- or counter-cyclical effects (see, inter alia, Bernanke and Gertler 1989, Hopenhayn 1992, Francois and Lloyd-Ellis 2003), thus making the relationship between the macroeconomic variables and entrepreneurial entry ambiguous. As there is a positive effect of start-ups on growth (van Stel et al. 2005), its direction matters: pro-cyclical effects may constitute the risk that cycles are amplified. This seems to be particularly important, as it may slow recovery during recessions if entrepreneurial entry lags behind the business cycle (Clementi and Palazzo 2016). In contrast, counter-cyclical effects could be beneficial for the economy when the opening of more businesses leads the cycle (Koellinger and Thurik 2012) -it could spur economic recovery during recessions, while a decline of start-ups in boom periods would not further enhance GDP growth. ${ }^{5}$

Empirical analyses of how these two macroeconomic factors influence business entries report mixed results (Parker 2012a; Sanchis et al. 2015). However, the great majority of existing research uses only the total number of firm entries, the total number of transitions into self-employment, or the changes in self-employment rates as outcome variable (see inter alia Thurik et al. 2008 or Congregado et al. 2012), and analyzes how business cycles influence this total number of entrepreneurial entries. Hence, these approaches do not account for different conditions and characteristics of industries. Therefore, it is not only the direction of the effects that is unknown, but also the composition of new businesses in terms of quality. To what extent do the different stages of the cycle affect innovative start-ups that may generate considerable impulses for growth and to what extend do they affect marginal businesses with less impact on the economy? In this context, Barlevy (2007) claims that radical innovation positively affects further new businesses to be ventured during boom periods, while Ghatak, et al. (2007), Roman, et al. (2013), and Köllinger and Thurik (2012) argue

\footnotetext{
${ }^{5}$ Note that a positive effect of start-ups on economic outcomes is observed because of its influence on GDP-growth (see, e.g., Carree and Thurik 2008). The economic effect of new firm formation on total employment is more complex, with positive influences in the short run (in the first two years) and then again in the long run after five years. In the medium term, i.e. between years 2 to 5 after a start-up, the employment effect turns out to be negative due to exits of established incumbents (see Fritsch 2013 for an overview of the empirical evidence).
} 
that recessions may especially stimulate the formation of marginal businesses because of falling wages and lower opportunity costs of entrepreneurial activity. Could it be that even if there is a counter-cyclical relationship between the cycle and the numbers of new businesses that small numbers of innovative businesses are more likely to be started during boom periods while large numbers of mostly marginal businesses are set up during recessions? The answer to this question is crucial for assessing whether new business formation has a stabilizing or a de-stabilizing effect over the business cycle.

This paper takes - to the best of our knowledge, for the first time-the quality and potential size of business entries into explicit account and investigates how much of the observed variations of the regional start-up rates in different types of industries is attributable to changes in region-specific cycles of GDP and unemployment. Using the start-up information of the ZEW Enterprise Panel, we perform the analysis at the level of NUTS 2 regions, which allows us to also control for regional differences with regard to a number of factors that may influence entrepreneurial entry, such as knowledge spillovers and employment in small businesses.

We mostly find correlations that are consistent with counter-cyclical effects on both innovative and non-innovative industries. The number of entries into large-scale industries including innovative manufacturing increases when unemployment is high and vice versa. The relationship between changes of GDP and entries into smallscaled businesses, including the knowledge intensive services is also counter-cyclical. Results remain robust when analyzing several sources of a potential bias, such as effect dynamics, unobserved spatial links, potential endogeneity, industry-specific business cycles, and the de-trending method.

In the following, Section 2 summarizes the current state of research on how business cycles relate to new business formation and presents a simple theoretical framework based on which we derive several research questions. We then introduce the data in Section 3. Section 4 presents our empirical approaches and describes the results of the analysis. Section 5 concludes. 


\section{Start-ups over the business cycle: theoretical and empirical research}

There is considerable variation in the number of new business formations across industries (Audretsch 1995). Such differences can be attributed to several factors, including an industry-specific minimum efficient size, differing capital requirements for starting a business, qualification requirements, the expected development of demand, as well as the availability and costs of industry-specific inputs (see Parker 2012a, for an overview). Due to these differences, the effect of the business cycle may vary considerably across industries.

First, this section reviews the theoretical and empirical literature on how cyclical changes in GDP and unemployment relate to the entry of new businesses (Section 2.1). Then, we present a conceptual framework that shows conditions on how business cycles influence start-up rates in different industries (Section 2.2) and that allows us to derive our research questions (Section 2.3).

\subsection{Overall effects of macroeconomic factors on start-ups}

The two main macroeconomic effects of interest are how cyclical variations in general economic activity, as represented by GDP and unemployment, affect the overall level of new business formation. Cyclical variations of these variables may influence entries through different channels.

\subsubsection{Effects of variations in GDP on start-ups}

There are various theories to understand how start-ups react to changes in business cycles (for an overview, see Parker 2012b). Caballero and Hammour (1994) propose a 'Schumpeterian model' of creative destruction where new businesses entering the market are more productive than older businesses, such that firm entry drives less productive incumbents out of the market. Based on the model of Hopenhayn (1992), according to which total demand drives entry and exit, they show that one should expect increasing entry rates during economic upswings and decreasing entry rates in 
recessions. ${ }^{6}$ While Caballero and Hammour's model proposes a pro-cyclical relationship between variations in GDP and the number business entries, ${ }^{7}$ it makes a point crucial to our analysis: business openings of 'Schumpeterian entrepreneurs' during recessions-although smaller in number than firm exits-may start firms that are more productive than those incumbents that exit. ${ }^{8}$

Previous research also emphasizes that supply side effects need to be considered. In particular, the development of resource prices is usually related to changes in GDP development. Production costs, rents, costs of capital and labor, and other relevant costs for business entries are typically lower during recessions than in boom periods (Lewis 2009). Low entry costs might make investments into new businesses during recessions more attractive, pointing to a counter-cyclical effect on entry.

Francois and Lloyd-Ellis (2003) and Barlevy (2007) present models where they consider firms aiming to invest into innovation activities. In both models, forward-looking demand expectations play a central role (in contrast to current demand), but the two models differ in one aspect, namely the timing when firms turn their inventions into innovation. In their model, Francois and Lloyd-Ellis (2003) argue that since resource costs are lower during recessions, entrepreneurs starting firms sensitive to such entry costs might prefer to launch their businesses during recessions, even if they made their invention in a boom period, thus leading to a counter-cyclical influence of business cycles on entrepreneurial entries. Barlevy (2007) claims that firms make more investments into R\&D during boom periods and then would not risk any delay, even if such a delay would be efficient from a cost point of view. He argues that entrepreneurs at the cost of inefficiency will not risk that potential competitors might "take their ideas away", i.e. commercializing the same idea earlier, leading to a pro-cyclical effect. Thus, the main reasons for the contradicting expectations of the two models are timing and opportunity costs.

\footnotetext{
${ }^{6}$ As Caballero and Hammour (1994) focus on the relative number of entries in relation to business closures, they also clarify that in case of increasing business entries during recessions, these increasing entry rates need to be overcompensated by even higher numbers of business exits given the reduced overall demand in such times.

${ }^{7}$ In a similar direction, Clementi and Palazzo (2016) argue more entrepreneurs may be attracted to enter markets in boom periods, when firms usually realize higher profits.

${ }^{8}$ Caballero and Hammour refer to the "cleansing effect of recessions" when they argue that entrepreneurs introducing superior technologies are able to displace inefficient incumbents.
} 
Koellinger and Thurik (2012) raise a different reason for why there may be more start-ups during recessions. By applying the prospect theory to start-up decisions, they argue that, "innovative business ideas that entail high risk are more likely to be pursued by individuals who suddenly have lower opportunity costs of self-employment than before, for example, as result of a salary cut or of unemployment in a recession" (Koellinger and Thurik 2012,1153). This is because in such situations of a loss position in relation to the prospect theory's reference point, individuals might have a lower risk awareness and act less uncertainty averse. According to this claim, there should be more start-ups during recessions. ${ }^{9}$

There is as much empirical support for both views as theoretical reasoning. Lee and Mukoyama (2015), who restrict their analysis to manufacturing plants, and Clementi and Palazzo (2016), who analyze the overall entry rates for the US, report pro-cyclical effects of output growth on business entries. In turn, Glaeser et al. (2010) show that more entrepreneurs enter the market when fixed costs are lower, which usually holds for recessions. Fritsch, Kritikos and Pijnenburg (2015), who analyze the overall entry rates for Germany, find that new business formation is higher during recessions than in boom periods. ${ }^{10}$ Congregado et al. (2012), who were the first to distinguish between employers (self-employed with employees) and non-employers (solo self-employed), regressing business cycles on changes in the population of these two kinds of self-employed, find a pro-cyclical correlation between changes in GDP and the number of employers as well as a counter-cyclical correlation for nonemployers. Hence, cyclical changes in GDP can have both pro-cyclical and countercyclical effects on business entries (see Hundt and Sternberg 2016), with the latter result of Congregado et al. (2012) pointing to the fact that effect directions may differ. However, it remains unclear which effect prevails in what type of industry.

\footnotetext{
${ }^{9}$ In his overview-paper, Parker (2012b) discusses a contrasting point to this approach. He presents the model of Rampini (2004), where the relationship between entrepreneurs and risk averse investors is analyzed in a moral hazard environment. As Rampini assumes that risk aversion decreases with increasing wealth, wealthier investors are more willing to finance riskier entrepreneurs. Applied to business cycles where wealth is growing during boom periods, the willingness to finance entrepreneurs should also increase indicating a pro-cyclical effect of the business cycle on entrepreneurial entry.

${ }^{10}$ For further evidence, see also Parker, Congregado, and Golpe (2012).
} 


\subsubsection{Effects of variations in unemployment on start-ups}

The second business cycle variable, changes in unemployment, may unfold effects different from those of GDP changes. When unemployment is high, it seems plausible to assume that more individuals will set up a business out of unemployment, the so called 'refugee effect' (Thurik et al. 2008, Caliendo and Kritikos 2010). However, these kind of new businesses may favor industries where starting a firm requires relatively few resources and where the minimum efficient size is comparatively low, such as in small-scale services (Roman et al. 2013). Consequently, high unemployment may particularly induce entries on the extensive margin (the number of firms). During times of low unemployment, the number of entries into such industries may be expected to be lower because it is easier to find a job in dependent employment.

In contrast, the prosperity pull hypothesis argues that during times of low unemployment, newly ventured businesses face higher consumer and firm demand for their products and services as more people have jobs, thus increasing their potential profits, and vice versa. If that influence should prevail, fewer businesses would be expected to be opened during times of high unemployment and there should be more start-ups when unemployment is low (Parker 2012a).

However, neither the unemployment-push nor the prosperity pull hypotheses account for the availability of resources that may be particularly relevant for firm formation at the intensive margin, i.e. when entrepreneurs aim to establish larger businesses with significant numbers of dependent employees. One may argue that such ambitious start-ups find more favorable conditions during periods of high unemployment not primarily because the business founders themselves are unemployed, but because high unemployment improves the availability of labor at relatively low wages. This may be particularly relevant for the venturing of innovative businesses needing labor (Francois and Lloyd-Ellis 2003). Thus, high unemployment may also have a positive effect on the number of entries into industries where business founders aim to create large-scale firms.

Examining the empirical evidence for Great Britain, Robson (1998) finds no support for a recession push effect, while Georgellis and Wall (2000) do, as they report a positive relationship between increasing unemployment and entrepreneurial entry. Foti and Vivarelli (1994) for Italy, Fairlie (2013) for the US, and Fritsch, et al. 
(2015) for Germany arrive at similar results. ${ }^{11}$ Hence, the overall picture regarding the effect of unemployment on new business formation is more conclusive. Nearly all studies point to a counter-cyclical influence, i.e. more businesses are established when unemployment is high, while we are not aware of any evidence supporting the prosperity-pull hypothesis.

This brief outline of possible relationships between the cyclical variations in macro-economic variables and overall new business formation shows that it is far from clear how these factors influence start-up behavior, even if changes in unemployment seem to unfold more counter-cyclical influences on start-up behavior than changes in GDP. Since differing effects may be observed for entries into different types of industries, it is important to distinguish between such industries in terms of potential firm size and innovativeness. Current profits, or expectations about future profits, in combination with entry costs, resource costs, and opportunity costs, can be assumed to unfold different effects in each individual industry type. For instance, the availability of labor or lower labor costs may affect entries into the manufacturing industries, while this availability or cost factor might essentially be irrelevant for small start-ups in knowledge-intensive services.

\subsection{Industry-specific effects: theoretical background}

The aforementioned theories, in Section 2.1, provide an overview on which variables may affect business entries. In this section, we aim to conceptualize how these variables, which are connected to changes in the business cycles, result in an industryspecific influence on start-up rates.

To provide a theoretical background, we construct and solve, based on Mortensen and Pissarides (1994), a simple matching model. Following Hopenhayn (1992), we analyze the comparative statics of this model in order to provide a rationale of possible channels depicting how the cyclical variables of GDP and unemployment unfold differing influences on new business formation, taking different sizes as well as the innovativeness of new businesses into account. To motivate our theoretical framework, we argue that industries crucially differ with regard to the necessity

\footnotetext{
${ }^{11}$ There is additional empirical evidence covering other countries, see Parker (2012a) or Fritsch, et al. (2015).
} 
of finding the capital required for starting a business. A start-up in consumer services will need a much smaller amount of capital than a high-tech start-up in innovative manufacturing. Risks connected to these investments may also greatly differ. Therefore, our focus is on the search and matching between investors and entrepreneurs as this approach mirrors industry specific differences through the financing channel.

The model builds on previous research emphasizing the problem of "entrepreneurial state verification" (Bernanke and Gertler 1989). For an investor, it is unclear if an entrepreneurial idea will succeed and if the entrepreneur will exhibit enough effort. In the model, investors must pay a cost to verify entrepreneurial ideas. If investors are willing to pay the control and verification costs, entrepreneurs and investors can be paired such that a business is started. However, entrepreneur-investor pairs can also separate if ideas fail or entrepreneurs do not manage their business well enough—generating new business formation as well as market exits. Based on previous findings, we then consider total demand, resource as well as opportunity costs, and analyze under what conditions supply side or demand side effects predominate during business cycles, which may either counter- or pro-cyclically affect entrepreneurial entries in certain types of industries.

\subsubsection{Agents}

All model agents are business-cycle takers, i.e. they react to changes in effective wages and sales opportunities, which are, in turn, determined by exogenous shocks, but cannot influence them. Furthermore, all agents are price takers. The first two types are investors, denoted by $i$, and potential entrepreneurs, denoted by $\ell$. Potential entrepreneurs have entrepreneurial ideas. To realize an idea, a potential entrepreneur must be paired with an investor, as the investor is endowed with resources that can be used to start a business. In case of very small businesses, the investor and entrepreneur can be the same person and the matching probability is nearly 1 .

Entrepreneurs can be of two different subtypes. They can be active entrepreneurs, denoted by $e$, if they are paired with an investor; or they can be potential entrepreneurs currently in wage work, denoted by $v$, if a match did not take place or a match was destroyed. The third type of agent are pure workers who work for entrepreneurs, but who do not have entrepreneurial ideas or lack the willingness or ability to put such an idea into practice. 
For the sake of simplicity, we assume that the supply of investors is potentially infinite (as it holds for small open economies) and that entry for investors is free. The number of potential entrepreneurs is normalized such that $\ell(t)=\ell=1$ for all $t$, where time is continuous and the type variable denotes the number of agents. Given a fixed number of potential entrepreneurs, the number of active entrepreneurs in period $t$ is $e(t)=1-v(t)$.

Investors and potential entrepreneurs are risk-neutral and discount future income with a rate $\delta \in(0,1)$. Pure wage workers have only one source of income such that their risk preferences and discounting factors do not matter. Pure wage workers and potential entrepreneurs in wage work receive a utility flow corresponding to the expected wage. More specifically, pure wage workers receive $(1-\vartheta) w(y)$, where the real wage $w(y)>0$ increases in sales opportunities $y>0$ and $\vartheta \in(0,1)$ is the general probability of unemployment. An increase in unemployment makes it harder to find a job such that the expected wage is reduced. Potential entrepreneurs in wage work receive utility flow $\beta(1-\vartheta) w(y)$, where $\beta \in\left\{1,(1-\vartheta)^{-1}\right\}$ describes how strongly potential entrepreneurs are directly influenced by the general unemployment rate. We assume (as in Holmes and Schmitz 1990) that individuals with low skills have a low potential for innovation (corresponding to so-called necessity entrepreneurs) and are strongly influenced by movements in the unemployment rate such that $\beta=1$. For this type of individual, avoiding unemployment-in the model, higher unemployment reduces the expected wage-is a strong incentive to start an own business. Individuals with high skills who have a high potential for introducing innovations (corresponding to opportunity entrepreneurs) are assumed to be barely influenced by changes in unemployment such that $\beta \approx(1-\vartheta)^{-1}$. For this type, there is almost no incentive to avoid unemployment by venturing a business.

An entrepreneur produces and sells $y$, pays $\gamma(1-\vartheta) w(y)$ to pure wage workers, ${ }^{12}$ where $\gamma \geq 0$ is the number of workers required to produce the product, and receives entrepreneurial income $\pi$. An investor, matched with an entrepreneur, receives an income flow of $y-\gamma(1-\vartheta) w(y)-\pi$. In addition to considering different potentials

\footnotetext{
12 The model only accounts for resource costs, where resources are pure wage workers required in the production process. Resource availability (the number of wage workers available for employment) has similar effects, as increasing scarcity of resources leads to higher resource costs.
} 
for innovation, we assume that businesses can be of two different sizes. First, businesses may be mostly driven by entrepreneurs who do not require a significant number of employees, such that $\gamma=0$. Examples of entrepreneur-driven businesses are firms providing services that mostly require specialized knowledge, but not extensive amounts of labor (such as in knowledge intensive services). Other businesses may require a larger number of paid employees, $\gamma>0$, for example, in manufacturing.

\subsubsection{Matching}

To generate a match, a combination of an investor and an entrepreneur constituting a firm, investors post project vacancies $p$. An investor pays a fixed per-period cost given by $c>0$ to post a project vacancy and to be ready for a business start-up. This cost can be interpreted as the verification cost of an entrepreneurial idea and a control cost of the entrepreneur. The matching rate of investors and potential entrepreneurs is denoted by $\theta(t)$. The matching rate of project vacancies is $\phi(t)$. New matches are formed according to a Poisson process. To create a match, individuals rely on a matching technology $M(p, v)=p^{1-\varepsilon} v^{\varepsilon}$, where $\varepsilon \in(0,1)$. Hence, the matching rate of investors and potential entrepreneurs is

$$
\theta(t)=p(t)^{1-\varepsilon} v(t)^{\varepsilon} v(t)^{-1}=\lambda(t)^{1-\varepsilon}
$$

where $\lambda(t) \equiv p(t) v(t)^{-1}$. The matching rate of project vacancies is

$$
\phi(t)=p(t)^{1-\varepsilon} v(t)^{\varepsilon} p(t)^{-1}=\lambda(t)^{-\varepsilon}
$$

Matches are separated according to a Poisson process with a time-invariant separation rate $\sigma$. Based on the matching outcomes, the steady state number of entrepreneurs can be easily determined (see Appendix $C$ for an analysis of the steady state outcome).

\subsubsection{Comparative statics}

Based on the steady state analysis provided in Appendix $\mathrm{C}$, we determine how the parameters GDP, i.e. sales opportunities, $y$, and unemployment, $\vartheta$, influence the steady-state number of entrepreneurs. For clarification, we label the effect of GDP to be pro-cyclical if the number of entries increases when GDP is high; the effect of unemployment is said to be pro-cyclical if the number of new businesses increases when unemployment is low. If the number of entries increases when GDP growth is low or 
unemployment is high we speak of a counter-cyclical effect. The effect is called acyclical if there is no effect of the business cycle on new business formation.

We consider four types of businesses:

Type 1: Entrepreneurs are low skilled and have a low potential for innovation, while they expect to employ no or only a small number of workers $(\beta=1$ and $\gamma=$ $0)$. We also assume that for this type, entrepreneurs and investors can be the same person. In such a case, the cost to control the entrepreneur is nearly zero, which drives down the cost $c$. Using (C3) in Appendix C, a low cost $c$ implies a high matching rate, which approaches 1 as $c$ goes to zero. Examples of Type-1 businesses include trade or consumer services.

Type 2: Entrepreneurs have a low potential for innovation, but they aim to create large scale businesses ( $\beta=1$ and $\gamma>0$ ). Businesses of the second type include, for instance, the non-innovative manufacturing industry.

Type 3: Entrepreneurs are high-skilled and have the potential to introduce innovation, but their business is expected to be small-scale $\left(\beta \approx(1-\vartheta)^{-1}\right.$ and $\left.\gamma=0\right)$, e.g. entrepreneurs in knowledge intensive services.

Type 4: The last type consists of high-skilled entrepreneurs with a high innovation potential running large scale businesses $\left(\beta \approx(1-\vartheta)^{-1}\right.$ and $\left.\gamma>0\right)$. An example of the fourth type is innovative manufacturing.

Given the four different types, which combine innovation potentials and scale, we derive type-specific effects. The steady-state number of entrepreneurs, derived in Appendix $\mathrm{C}$, is given by

$$
e^{*}=\frac{\theta^{*}}{\sigma+\theta^{*}}
$$

where the equilibrium matching rate is

$$
\theta^{*}=(1-\rho)^{\frac{1-\varepsilon}{\varepsilon}}\left[\frac{y-(\gamma+\beta)(1-\vartheta) w(y)}{c[\delta+\sigma]}\right]^{\frac{1-\varepsilon}{\varepsilon}}
$$

Using (3) it is easy to show, that the GDP effect is pro-cyclical if $w^{\prime}(y)<w^{*}$, counter-cyclical if $w^{\prime}(y)>w^{*}$, and a-cyclical if $w^{\prime}(y)=w^{*}$. In its most general form, the critical value is given by

$$
w^{*}=(1+\gamma)^{-1}(1-\vartheta)^{-1}
$$


Thus, the reaction to GDP depends on the marginal reaction of wages to sales opportunities $y$. The term $w^{*}$ represents a critical value for the increase in opportunity cost and resource costs during a boom. If opportunity and resource costs are too high when GDP is high, GDP effects can become counter-cyclical. Table 1 summarizes conditions for all GDP effects depending on the four types.

The results on the effect of unemployment are more definite. Using (3), it is straightforward to show that

$$
\frac{\partial e^{*}}{\partial \vartheta}>0
$$

Thus, the effect of unemployment is counter-cyclical, as more businesses are started if unemployment increases. However, for Type 3, for whom the risk of becoming unemployed is low and who does not plan to employ labor, the size of unemployment effects might be rather small as

$$
\lim _{\beta \rightarrow(1-\vartheta)^{-1}} \frac{\partial e^{*}}{\partial \vartheta}=0
$$

Note that the model does not provide predictions with respect to the time dimension of reactions, as a comparative statics analysis only compares steady states. Hence, it remains an open question whether reaction time differs across industries.

\subsection{Research questions}

Given the four different types and the type-specific effects, we briefly relate these predictions to earlier findings discussed in Section 2.1, before we formulate several research questions. First, since a rise (a decline) in GDP increases (decreases) production costs, the effect of GDP depends on the balance between demand side effects, i.e. better current or future sales opportunities, and supply side effects, i.e. the opportunity and resource costs of entrepreneurship (the alternative wage income, the production and resource costs etc.). Which of these effects prevail remains an empirical question (see also Lewis, 2009). In line with Barlevy (2007), it might be expected that the demand side effect will dominate and that GDP will generate pro-cyclical effects, in particular if we consider Types 1 and 3, as these types are mostly based on entrepreneurial labor. For Types 2 and 4, relying on paid employees, the cost aspect will dominate if the number of wage workers employed is sufficiently large, as 


$$
\lim _{\gamma \rightarrow \infty}(1+\gamma)^{-1}(1-\vartheta)^{-1}=\lim _{\gamma \rightarrow \infty}(1+[1-\vartheta] \gamma)^{-1}=0 \text { and } w^{\prime}(y)>0
$$

and the GDP cycle will produce counter-cyclical effects.

Table 1: Conditions for GDP effect directions

\begin{tabular}{|c|c|c|c|}
\hline & $\begin{array}{l}\text { Demand side effects } \\
\text { leading to pro-cyclical } \\
\text { influences of business } \\
\text { cycle variables }\end{array}$ & $\begin{array}{l}\text { Supply side effects lead- } \\
\text { ing to counter-cyclical in- } \\
\text { fluences of business cy- } \\
\text { cle variables }\end{array}$ & $\begin{array}{l}\text { Conditions under which } \\
\text { supply side or demand } \\
\text { side effects dominate }\end{array}$ \\
\hline $\begin{array}{l}\text { Type 1: Non-in- } \\
\text { novative, small } \\
\text { business entries }\end{array}$ & $\begin{array}{l}\text { Higher current demand } \\
\text { Prosperity pull hypothe- } \\
\text { sis }\end{array}$ & $\begin{array}{l}\text { Entry costs } \\
\text { Opportunity Costs } \\
\text { Refugee effect }\end{array}$ & $\begin{array}{l}\text { The effect of GDP is } \\
\text { pro-cyclical if } w^{\prime}(y)< \\
(1-\vartheta)^{-1}, \text { a-cyclical if } \\
w^{\prime}(y)=(1-\vartheta)^{-1} \text {, and } \\
\text { counter-cyclical if } \\
w^{\prime}(y)>(1-\vartheta)^{-1}\end{array}$ \\
\hline $\begin{array}{l}\text { Type 2: Non-in- } \\
\text { novative, large } \\
\text { business entries }\end{array}$ & $\begin{array}{l}\text { Higher current demand } \\
\text { Prosperity pull hypothe- } \\
\text { sis }\end{array}$ & $\begin{array}{l}\text { Entry costs } \\
\text { Resource Costs } \\
\text { Opportunity Costs } \\
\text { Availability of resources }\end{array}$ & $\begin{array}{l}\text { The effect of GDP is } \\
\text { pro-cyclical if } w^{\prime}(y)< \\
(1+\gamma)^{-1}(1-\vartheta)^{-1} \text {, a-cy- } \\
\text { clical if } w^{\prime}(y)=(1+ \\
\gamma)^{-1}(1-\vartheta)^{-1} \text {, and coun- } \\
\text { ter-cyclical if } w^{\prime}(y)> \\
(1+\gamma)^{-1}(1-\vartheta)^{-1}\end{array}$ \\
\hline $\begin{array}{l}\text { Type 3: Innova- } \\
\text { tive, small busi- } \\
\text { ness entries }\end{array}$ & $\begin{array}{l}\text { Higher current or future } \\
\text { demand } \\
\text { Prosperity pull hypothe- } \\
\text { sis }\end{array}$ & $\begin{array}{l}\text { Entry costs } \\
\text { Opportunity Costs }\end{array}$ & $\begin{array}{l}\text { The impact of GDP is } \\
\text { pro-cyclical if } w^{\prime}(y)<1 \text {, } \\
\text { a-cyclical if } w^{\prime}(y)=1 \text {, } \\
\text { and counter-cyclical if } \\
w^{\prime}(y)>1\end{array}$ \\
\hline $\begin{array}{l}\text { Type 4: Innova- } \\
\text { tive, large busi- } \\
\text { ness entries }\end{array}$ & $\begin{array}{l}\text { Higher current or future } \\
\text { demand } \\
\text { Prosperity pull hypothe- } \\
\text { sis }\end{array}$ & $\begin{array}{l}\text { Entry costs } \\
\text { Resource Costs } \\
\text { Opportunity Costs } \\
\text { Availability of resources }\end{array}$ & $\begin{array}{l}\text { The effect of GDP is } \\
\text { pro-cyclical if } w^{\prime}(y)< \\
(1+[1-\vartheta] \gamma)^{-1}, \text { a-cycli- } \\
\text { cal if } w^{\prime}(y)=(1+[1- \\
\vartheta] \gamma)^{-1} \text {, and counter-cy- } \\
\text { clical if } w^{\prime}(y)>(1+[1- \\
\vartheta] \gamma)^{-1}\end{array}$ \\
\hline
\end{tabular}


To see why there might be differences in type-specific reactions to GDP, consider a simple numerical example: assume that the probability of unemployment is $5 \%$. Furthermore, assume that if an entrepreneur requires labor, she will employ 10 individuals. Using both values, we obtain the following critical increases in wages in an economic upswing:

Table 2: Conditions for GDP effect: an example

\begin{tabular}{ll}
\hline Type & Critical increase in wages \\
\hline Type 1: Non-innovative, small business entries & $w^{*} \approx 1.05$ \\
Type 2: Non-innovative, large business entries & $w^{*} \approx 0.01$ \\
Type 3: Innovative, small business entries & $w^{*}=1.00$ \\
Type 4: Innovative, large business entries & $w^{*} \approx 0.01$ \\
\hline
\end{tabular}

If the wage increase is above the critical value, GDP unfolds a counter-cyclical effect and vice versa. In Table 2, we observe that if two entrepreneurs with the same innovation potential aim to start a business, the entrepreneur planning to employ a large amount of labor has a substantially lower critical value for a counter-cyclical GDP effect. If, for instance, for every additional dollar of demand the wage increases by 2 cents, Type 2 and 4 will react counter-cyclically, whereas Type 1 and 3 react pro-cyclically. There is thus a pronounced size effect with respect to reactions to GDP.

As to the second business cycle variable, unemployment, according to our model we expect that variations in the unemployment rate may influence potential entrepreneurs in different ways depending on their skill level and the planned size of their business. For individuals with low skills, an increase in unemployment makes it more difficult to find a job, such that avoiding unemployment leads to a stronger incentive to start an own business (the 'refugee effect'). Entrepreneurs who plan to venture businesses with a larger number of employees may be more likely to start their ventures in times of high unemployment when it is easier to find the required workers. The only exception are high-skilled entrepreneurs running small businesses. On the one hand, these types are less affected by the risk of unemployment; as they may move more easily between alternative job opportunities. On the other hand, they do not employ others in large numbers, which is why we expect that Type 3 does not 
react to changes in unemployment. Therefore, except for Type 3 entries, we predict that changes in unemployment generate counter-cyclical effects. ${ }^{13}$

Based on these considerations, we investigate the following three questions:

(1) To what extent are there differences in the influence of cyclical variables on new business formation, when distinguishing (a) between large and small-scale industries and $(b)$ between innovative and non-innovative industries?

(2) Cyclical variations in GDP: (a) Are demand side effects, such as expectations about current or future profit opportunities, more or less important for new business formation than supply side effects (e.g., opportunity costs, production and resource costs, other entry-related costs), leading to pro-, a-, or counter-cyclical influences of GDP on business entry? (b) To what extent does the innovativeness and the minimum efficient size (large or small scaled) of a ventured business matter in the cyclical relationship between changes in GDP and business entries?

(3) Cyclical variations in unemployment: to what extent do changes in unemployment unfold (a) counter-cyclical influences on entries of firms with a low innovation potential that do not expect to employ a large number of personnel (Type 1), and (b) any influence on entries of firms with a high innovation potential where the entrepreneurs themselves are less affected by unemployment risks and do not intend to employ a large number of personnel (Type 3)? (c) To what extent do changes in unemployment unfold counter-cyclical influences on entries of firms that expect to employ a larger number of employees (Type 2 and 4) at times of high unemployment when labor is more easily available?

\section{Data and classification of industries}

\subsection{Data}

For our analysis, we use data on start-ups from the Enterprise Panel collected by the Center for European Economic Research (ZEW-Mannheim). This source includes nearly all firms established between 1995 and 2013. ${ }^{14}$ The data are based on information from Creditreform, Germany's largest credit rating agency, and is the only source that allows for identifying innovative start-ups based on their affiliation with certain industries. Like other data sources on start-ups, these data may not have

\footnotetext{
${ }^{13}$ We should emphasize that there is no empirical support for the prosperity pull hypothesis.

${ }^{14}$ However, we cannot use the whole data set as covariates are not available for the whole period.
} 
complete coverage of solo-entrepreneurs. ${ }^{15}$ However, once the firm either is registered, hires employees, asks for a bank loan, or unfolds reasonable economic activities even as a solo-entrepreneur, it is included in the data set and information is gathered on the date when the firm was established. Most solo-entrepreneurs are captured, including their business founding date (for details see Bersch et al. 2014).

In our analysis, we differentiate between a number of industries according to their innovativeness and knowledge intensity covering all parts of the private economy in Germany, except agriculture. ${ }^{16}$ Within manufacturing, we apply the common classification of industries according to their presumed innovativeness. In our first group, we include high-technology manufacturing industries spending more than 9 percent of their annual turnover on Research and Development (R\&D), as well as technologically advanced manufacturing industries with R\&D intensities between 3 and 9 percent (OECD 2005; Gehrke et al. 2013). These two types of industries are separated from the non-technology oriented manufacturing industries that spend less on R\&D, and from the industries construction, and energy and mining.

Since the service sector is heterogeneous, we distinguish between a number of different sub-sectors, starting with the traditional services such as trade, transport and postal services. The business oriented services comprise the "other" business services and the knowledge intensive services, which again consist of technology oriented services (architectural and engineering activities, technical consultancy, and technical testing and analysis), as well as other non-technology oriented services. As further categories, we have credit and insurance (separately from the business services) and consumer oriented services comprising hospitality, real estate services, health care, culture, sports and entertainment, social services, and education.

\footnotetext{
${ }^{15}$ Alternative data sources on start-up activities in Germany are the Micro-census published by the German Statistical Office, the business registration statistics, and the statistics from the Federal Employment Agency (FEA). However, neither the Micro-Census nor the business registration statistics would allow for an analysis at the industry level as this information is missing. The only other data source containing this information is the statistics of the FEA. However, in these data, start-ups are only registered at the time when they hire their first employee. Therefore, start-up activities are only partly covered. In contrast to this, the data provided by the ZEW are better suited for our approach. These not only differentiate between start-ups according to the industry classification, but also cover most solo entrepreneurs (for more details see Fritsch, Kritikos, Rusakova, 2012).

${ }^{16}$ For the classification of industries, see Table A1. Agriculture is excluded because new business formation in this sector represents a rather special case that is hardly comparable to other sectors.
} 
Many investigations of the relationship between entrepreneurship and the business cycle use changes in the stock of entrepreneurs as the dependent variable (net entry). In contrast, our analysis is based on transitions into self-employment (gross entry). Gross entry is better suited to identify how macro-variables influence entrepreneurship at the industry level as this variable provides information about the dynamics of the economy (see Caballero and Hammour 1994). Net entry conceals changes in the gross flows (for an extended discussion, see Fritsch, et al. 2015). Hence, we expect to reveal the relevant relationships more reliably than an analysis based on net entry. For a description of all variables used, see Table A2.

The Federal Employment Agency (Bundesagentur für Arbeit) provides information on the number of unemployed persons and unemployment rates. The unemployment rate is defined as the share of registered unemployed over the entire working population, comprising all employed plus the registered unemployed. The nominal GDP at the NUTS 2 level is annually provided by Volkswirtschaftliche Gesamtrechnung der Länder (Macroeconomic Accounting of the Federal States; Statistisches Bundesamt a, various volumes) for the 1994-2012 period. In order to obtain real values of GDP, the nominal figures are deflated by using the annual Consumer Price Index (CPI) of the Federal Statistical Office (Statistische Bundesamt b, various volumes). Since CPI information is only available for Federal States, but not for NUTS 2 regions, we deflate the nominal GDP at the NUTS 2 level by using the regional CPI of the corresponding Federal State.

The cyclical component of the unemployment rate and of real GDP is generated applying the Hodrick-Prescott filter (Hodrick and Prescott 1997). This filter is a statistical tool widely used in empirical analyses for separating the cyclical component of economic development from the corresponding trend (Montoya and de Haan 2008). The two components are estimated in a way that, over long periods, the sum of the deviations of the cyclical component from the trend is close to zero, thereby minimizing the variability of the growth component. The so-called smoothing, or HP filter parameter, determines the variability of the growth component. The larger the HP filter parameter, the smoother is the trend component. Following Ravn and Uhlig (2002), we use a HP filter parameter of 6.25 for annual data. ${ }^{17}$

\footnotetext{
${ }^{17}$ Using other plausible values of the HP filter parameter does not lead to fundamental changes in the results. We also discuss the use of a different filter in Section 4.3.3. The deviation from the trend of
} 


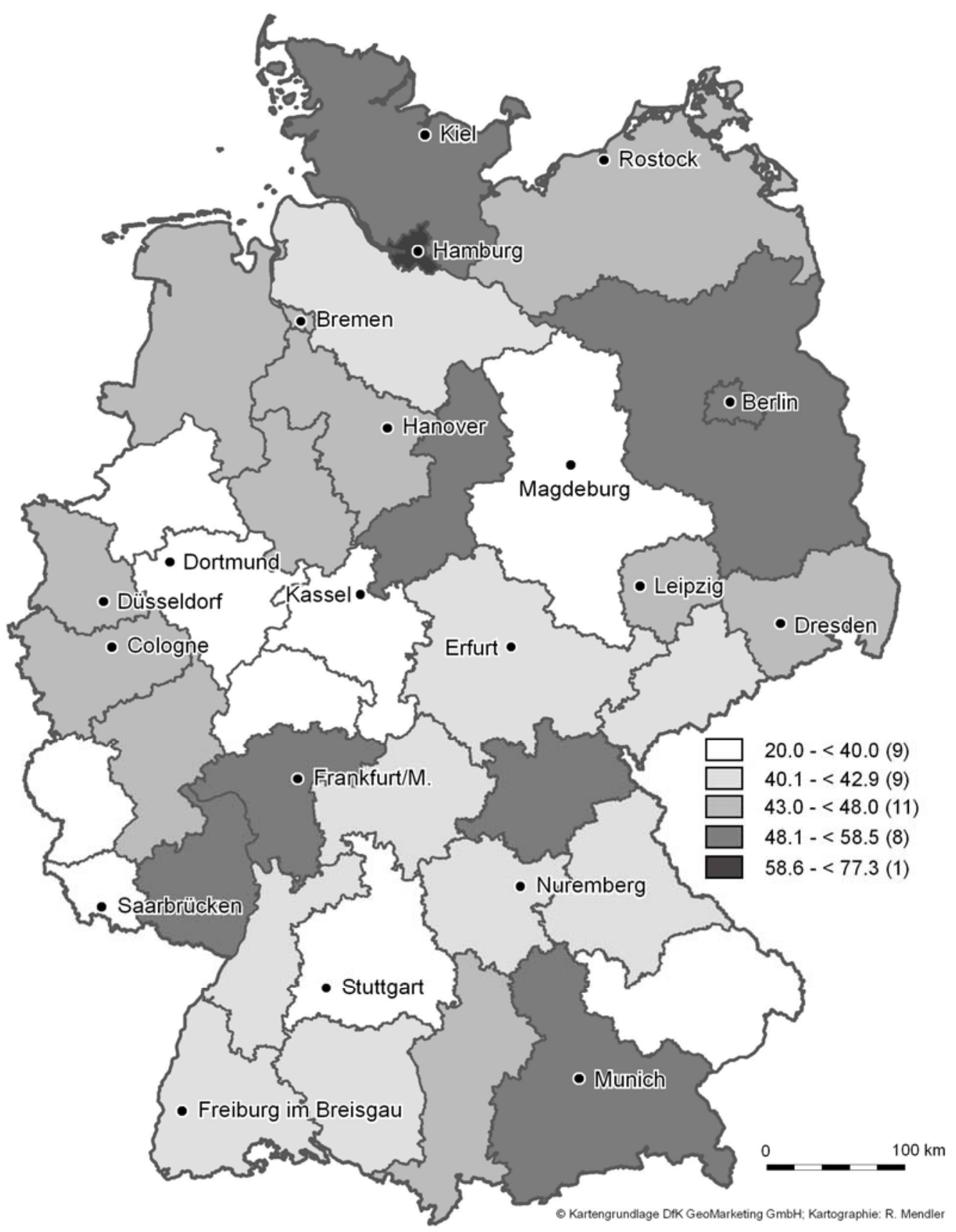

Figure 1: Distribution of average start-up rates of the 1995-2008 period across German NUTS 2 regions

When focusing on innovative business start-ups that require both significant R\&D investments and highly skilled employees, it is important to control for other macroeconomic factors; in particular, those related to knowledge spillovers that also 
influence entries in such industries. In our approach, we consider four factors that are consistent with the Knowledge Spillover Theory of Entrepreneurship (see Audretsch et al. 2006; Acs et al. 2009), which regards new business as a knowledge spillover from universities, research institutes, and, in particular, incumbent firms. These factors are the share of employees in small businesses, the share of workforce with a tertiary degree, the number of university professors, and the number of patents as a proxy for R\&D output for each NUTS 2 region.

Previous research shows that employees who have worked in small firms have a higher propensity to spin-off and start an own business (Parker 2009; Elfenbein et al. 2010). Research also shows that the venturing of new businesses is higher in regions where the number of individuals holding a tertiary degree is high. ${ }^{18} \mathrm{We}$ account for both variables by using information on the regional employment share in establishments with up to 20 employees and the share of highly qualified employees, both coming from the Establishment History File of the German Employment Statistics, which covers all employees subject to compulsory social insurance contributions (Spengler 2008). It is also known that the proximity to universities matters, as startups seek to exploit the regional knowledge stock from these institutions (Audretsch et al. 2006; Fritsch and Aamoucke 2017). We approximate for the knowledge stock by providing information on the number of professors per 1,000 workforce population (see German Federal Statistical Office-Hochschulstatistik des Stat. Bundesamts). ${ }^{19}$

Finally, a higher level of research output may also induce higher start-up rates (see Shane 2001). To account for this influence, we include the yearly number of patent applications per 1,000 workforce population as a measure of a region's knowledge capital; this is provided by the RegStat database. The low correlation between the number of professors and the number of patents (see Table A3 in the Appendix) suggests that the two variables represent distinct types of knowledge that show considerable divergence in their importance across industries. Since a Breitung

\footnotetext{
${ }^{18}$ According to the Knowledge Spillover Theory of Entrepreneurship, such knowledge should be conducive to start-ups, particularly in innovative and knowledge-intensive industries (Acs, et al. 2009). Fritsch and Aamoucke (2017) find that such effects of regional knowledge on new business formation in innovative industries are highly localized and hardly spill over to adjacent regions.

${ }^{19}$ The analyses of the role of public research institutions for innovative start-ups in Germany by Fritsch and Aamoucke (2017) show that the number of professors can be regarded a good representation of the respective knowledge stock.
} 
(2000) panel unit root test reveals that the levels of these independent variables are not stationary, they are included as growth rates.

Given restrictions due to data availability (of covariates) and necessary transformations of independent variables ${ }^{20}$ (like the computation of growth rates), the time dimension of the analysis covers 13 years, from 1996 to 2008.

\subsection{Further Classification of industries}

In our conceptual analysis and the resulting research questions (Section 2.3), we distinguish between four types of start-ups according to the innovativeness and the potential size of their ventures. To address these research questions with data for industries, we need to assign these types of entrepreneurs to different industries. Table 3 presents such a classification of industries that is based on average values of innovativeness and minimum efficient size of the industries. According to the classification, typical Type 1 entries are in consumer oriented services, construction, and trade. The entries of Type 2 are in non-innovative large-scale industries, such as non-innovative manufacturing, transport, as well as energy and mining. Examples for innovative industries with low minimum efficient size, Type 3, are knowledge intensive services including technology oriented services as well as credit and insurance. Finally, innovative businesses at a larger scale, Type 4, are the high-tech and technologically advanced manufacturing industries. Of course, this classification cannot fully account for all heterogeneity of start-ups within industries. However, we argue that our analysis is sufficiently valid for an empirical test of our research questions.

A debatable case in this classification of industries, according to their minimum efficient size, is energy and mining. This industry traditionally consists of large-scale power plants and includes infrastructures for energy distribution that make entry rather difficult. However, it also comprises a growing share of firms that produce energy based on wind, solar power and water on a relatively small scale. Entries of such small-scale energy producers played a considerable role during our period of analysis. This industry may also represent a rather special case because it was subject to a high level of state intervention, incorporating changes to the regulatory framework as well as subsidization of energy production from renewable resources.

\footnotetext{
20 The independent variables enter the estimation with a time lag of one year. We further discuss the chosen lag structure in sections 3.3 and 4.1 .
} 
Table 3: Classification of industries according to innovativeness and minimum efficient size (scale)

\begin{tabular}{lll}
\hline Innovation / scale & Small scale & Large scale \\
\hline Non-innovative & $\begin{array}{l}\text { Type 1: Consumer oriented } \\
\text { services, construction, trade }\end{array}$ & $\begin{array}{l}\text { Type 2: Energy and mining, non-innovative } \\
\text { manufacturing, transport and postal services }\end{array}$ \\
Innovative & $\begin{array}{l}\text { Type 3: Credit and insurance, } \\
\text { knowledge intensive incl. tech- }\end{array}$ & $\begin{array}{l}\text { Type 4: High-tech and technologically ad- } \\
\text { valogy oriented services }\end{array}$ \\
\hline
\end{tabular}

\subsection{Descriptive statistics}

Table 4 reports descriptive statistics of the start-up rates in different industries. In the entire private sector (except agriculture), there are an average of 44 start-ups per 10,000 workforce per year (Table A4 in the Appendix provides further information on the average number of start-ups for the four start-up types in the regions). The largest numbers of new businesses are in consumer-oriented services, trade and business oriented services. Relatively low rates are found in manufacturing and in energy and mining. The start-up rates in high-tech manufacturing and technologically advanced manufacturing industries are lower than those in non-innovative manufacturing. In contrast, the number of new businesses in knowledge intensive services is higher (5.6 yearly start-ups per 10,000 workforce).

Overall, the summary statistics show considerable differences in the magnitude and the variation of business dynamics across sectors indicating that an analysis of the influence of the business cycle on start-ups should distinguish between industries. For instance, a high number of entries into consumer-oriented services may overcompensate for considerably smaller numbers of entries in the manufacturing sector or the technology-oriented services but these fewer start-ups may have stronger effects on future developments.

Examining entries over time, Figure 2 shows that the absolute number of startups is declining in most industries. This decline is stronger for Type 1, which is mostly driven by trade industries, partly explaining the high coefficient of variation in this industry (Table 4), but the total number of start-ups in the innovative industries also show a negative trend over the observation period (Types 3 and 4 in Figure 2). 
Table 4: Descriptive statistics for start-up rates in different industries

\begin{tabular}{lcccc}
\hline Start-up rate for & Mean & Minimum & Maximum & $\begin{array}{c}\text { Standard } \\
\text { deviation }\end{array}$ \\
\hline All private industries & 44.14 & 30.02 & 52.19 & 6.03 \\
- Energy and mining & 0.52 & 0.28 & 1.02 & 0.24 \\
- Construction & 5.34 & 3.30 & 7.40 & 1.17 \\
- Trade & 10.53 & 6.19 & 13.36 & 2.28 \\
- Transport and postal services & 1.84 & 1.17 & 2.24 & 0.27 \\
- Credit and insurance & 1.67 & 1.04 & 2.06 & 0.31 \\
- Consumer oriented services & 12.55 & 9.04 & 13.97 & 1.22 \\
- Manufacturing & 2.13 & 1.58 & 2.71 & 0.29 \\
- Non-innovative manufacturing & 1.73 & 1.30 & 2.13 & 0.22 \\
- Innovative manufacturing & 0.40 & 0.27 & 0.58 & 0.09 \\
$\quad$ - High-tech manufacturing & 0.11 & 0.07 & 0.16 & 0.06 \\
$\quad$ - Technologically advanced & 0.29 & 0.19 & 0.41 & 0.06 \\
$\quad$ manufacturing & 9.57 & 7.21 & 11.41 & 1.08 \\
- Business oriented services & 5.61 & 3.78 & 7.08 & 0.86 \\
- Knowledge intensive services & 2.79 & 1.95 & 3.69 & 0.48 \\
\hline
\end{tabular}

Notes: Yearly number of start-ups per 10,000 workforce in Germany.

The high correlation values of start-up rates within certain sectors reported in Tables A5 and A6 in the Appendix indicate correspondence between new business formation in different fields of economic activity. This is true for start-ups in different parts of the service sector, suggesting that similar factors trigger these start-ups.

The relationship of new business formation in manufacturing with the start-up activity in the service sector is less pronounced, while the correlation of new business formation within the innovative parts of manufacturing are high (Tables A5 and A6). An exception is the negative correlation of the start-up rates in energy and mining with the level of new business formation in other industries (Table A5).

Table 5 reports the correlation between start-up rates in different industries with the cyclical components of the unemployment rate and of GDP. Correlation is strongest for the cycle indicator that is lagged by one year $(t-1)$. While the relationship with the unemployment rate is nearly always positive, it tends to be negative for 
the cyclical component of GDP, particularly in years $t$ and $t-1$. The trade sector correlates most with the cyclical component of the unemployment rate, while correlations seem to be stronger for manufacturing than for services. When it comes to the cyclical component of GDP, the contemporaneous and one-year lagged correlation is usually negative, while the two-year lagged correlation is mostly positive, probably due to the sinusoidal wave pattern of this variable over time.

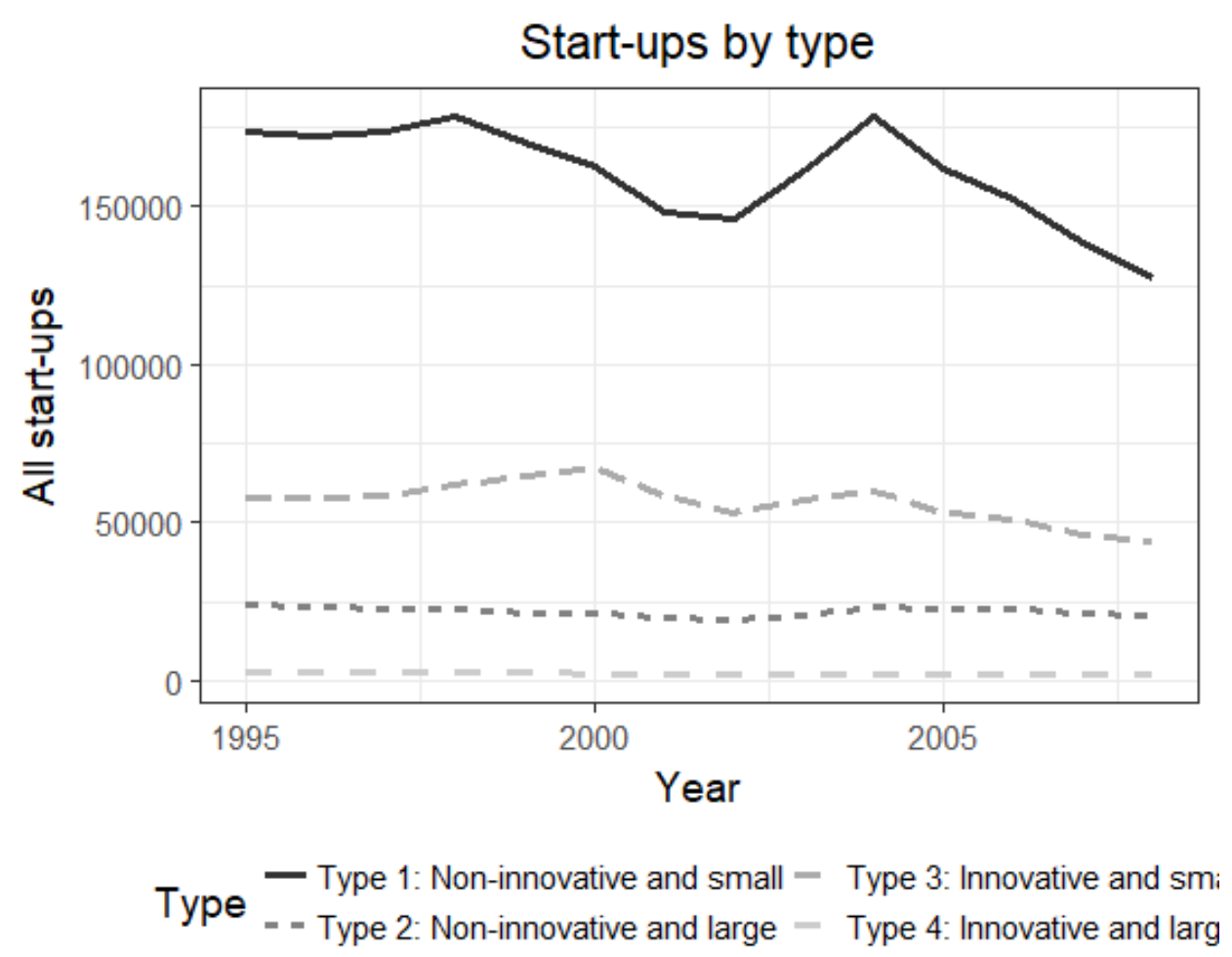

Figure 2: Yearly number of start-ups conditional on the four types of industries. For instance in 2004178,041 start-ups belong to type 1 .

These correlations suggest that the influence of the cycle on new business formation differs quite considerably across industries. According to the correlations, it takes an average of about one year for the business cycle to exert its main influence on the formation of new businesses. The correlation between the GDP cycle and the unemployment cycle is -0.39 (Table A3 in the Appendix), such that a multicollinearity problem due to a strong correlation between the cyclical components is unlikely. ${ }^{21}$ Therefore, we include the cyclical component of the unemployment rate and the GDP

\footnotetext{
${ }^{21}$ We also computed variance inflation factors, which did not indicate any multicollinearity problems.
} 
in all models. There is considerable variation in the GDP and unemployment cycle across regions, as shown in Figure $\mathrm{A} 1$ (in the Appendix), which depicts bi-regional correlations between the two cyclical components. ${ }^{22}$ The median bi-regional correlation of the GDP cycle is 0.55 and of the unemployment cycle 0.88 . Thus, the GDP cycle is less synchronized across regions than the unemployment cycle.

Table 5: Correlation between start-up rates in different sectors and business cycle variables

\begin{tabular}{lcccccc}
\hline & \multicolumn{3}{c}{$\begin{array}{c}\text { Unemployment rate }- \\
\text { cyclical component }\end{array}$} & \multicolumn{3}{c}{$\begin{array}{c}\text { Real GDP - cyclical } \\
\text { component }\end{array}$} \\
\hline All private industries & $T$ & $t-1$ & $t-2$ & $t$ & $t-1$ & $t-2$ \\
Energy and mining & 0.12 & 0.17 & 0.04 & -0.08 & -0.09 & 0.06 \\
Manufacturing & 0.00 & -0.04 & -0.09 & -0.05 & -0.11 & -0.03 \\
Non-innovative manufacturing & 0.16 & 0.19 & 0.01 & -0.16 & -0.12 & 0.10 \\
Construction & 0.16 & 0.18 & -0.02 & -0.18 & -0.14 & 0.08 \\
Trade & 0.18 & 0.17 & 0.04 & -0.05 & -0.06 & 0.03 \\
Transport and postal services & 0.19 & 0.25 & 0.05 & -0.09 & -0.10 & 0.08 \\
Credit and insurance & 0.06 & 0.15 & 0.08 & 0.00 & -0.06 & 0.02 \\
Business oriented services & 0.02 & 0.08 & 0.00 & -0.02 & -0.06 & 0.06 \\
Consumer oriented services & 0.00 & 0.04 & 0.02 & -0.04 & -0.03 & 0.04 \\
Innovative manufacturing & 0.07 & 0.11 & 0.02 & -0.06 & -0.08 & 0.04 \\
High tech manufacturing & 0.08 & 0.13 & 0.07 & -0.05 & 0.00 & 0.10 \\
Technologically advanced manufac- & 0.05 & 0.14 & 0.12 & 0.00 & -0.04 & 0.02 \\
turing & 0.07 & 0.09 & 0.03 & -0.08 & 0.03 & 0.12 \\
Knowledge intensive services & 0.00 & 0.06 & 0.03 & -0.05 & -0.04 & 0.05 \\
Technology-oriented services & 0.00 & 0.09 & 0.06 & -0.06 & -0.06 & 0.05 \\
\hline
\end{tabular}

\section{Empirical approaches and results}

This section presents our empirical results. We start by constructing the four types of businesses discussed in Sections 2.2 and 3.2, then analyzing how business cycles influence these four types of industries. Subsequently, we provide several robustness and sensitivity checks, including tests for endogeneity.

\subsection{Separate analysis for four types of industries}

We aim to assess whether there is evidence that start-up rates in the four types of industries systematically change with business-cycle variables. Therefore, we regress

\footnotetext{
22 The bi-regional correlation is computed as $\operatorname{Cor}\left(v_{i, t}, v_{j, t}\right)$ where $v$ is the cyclical component (of GDP or unemployment) and $i$ and $j$ are two regions with $i \neq j$.
} 
these start-up rates on the cyclical components of the unemployment rate and GDP, as well as on a set of control variables related to business entries. For our further analysis, we also need to scrutinize which time lag to use between the cycling variables and business entries. From a theoretical point of view, we argue that potential business entrants observe in period-year $\mathrm{t}-1$ an aggregate change of a cycling variable, for instance an increase in unemployment signaling higher availability of labor or an increase in GDP signaling more profit opportunities. ${ }^{23}$ In order to be able to take advantage of this impulse, individuals who react to such impulses, will decide in year $t$ to enter the market with their new firm, some may make the decision the latest in year $t+1$. The correlation analysis between business cycle variables and start-up rates (Table 5) points in a similar direction: the main part of the effect of the cycle on new business formation becomes effective within a one-year period. Thus, we suggest using a time lag of one year. ${ }^{24}$ Still, as the length of the relevant time period may differ not just across industries but also between booms and recessions, in the next section we provide a robustness check where we analyze the cumulative influence of changes in the business cycle in two previous years.

The same set of independent variables is included in all models in order to identify differences between industries. We apply a fixed effects panel approach to capture region-specific influences that are invariant over time. To reduce endogeneity problems, both cyclical components and all other explanatory variables are included with a time lag of one year (Astebro, et al. 2013). Still, we are aware that the fixed effects estimations do not reflect causal relationships. Therefore, we provide further tests for endogeneity in Section 4.2.3, when testing the robustness of our results. To allow for an assessment of the relative influence of the estimated coefficients, all variables are standardized with a mean value of zero and a standard deviation of 1 . The estimated equation has the form:

Startup rate ${ }_{i, t}^{\tau}=\mu_{i}^{\tau}+\alpha_{1}^{\tau} \mathrm{BC}$ unemployment ${ }_{i, t-1}+\alpha_{2}^{\tau} \mathrm{BC} \mathrm{GDP}_{i, t-1}+\boldsymbol{\eta}_{\tau}^{\top} \mathbf{x}_{i, t-1}+u_{i, t}^{\tau}(6)$

\footnotetext{
${ }^{23}$ As we use yearly data on GDP and on unemployment at the regional level, we argue that a change in that variables that happens in a certain month in $\mathrm{t}-1$ will be captured by data in the very same year.

${ }^{24}$ Note that earlier research mostly discusses the appropriate lag structure to capture the effect of changes in the levels of these variables on business entries (instead of the cycles); see e.g. Thurik et al. (2008). This needs a different justification of lag-structures.
} 
where $\tau \in\{$ Type 1, Type 2, Type 3, Type 4\} captures the industry type. The $i=$ $1, \ldots, N$ is the number of NUTS 2 regions; thus we only refer to regional cycles. ${ }^{25} t=$ $1, \ldots, T$ denotes the years, $\mu_{i}$ represents the fixed effects and $\mathbf{x}_{i, t}$ is the four-dimensional vector of control variables. The control variables (in $\mathbf{x}$ ) are, as shown in Section 3.1, the share of employees in businesses with up to 20 employees, the share of employees with a tertiary degree, the number of university professors, and the number of patent applications per 1,000 workforce. Note that the covariates are included as growth rates.

Table 6 presents the results of our fixed effects estimations. We start by analyzing how macroeconomic variables affect all start-ups in the overall private sector (left column in Table 6). We find positive correlations between the cyclical component of unemployment and negative correlations between the cyclical component of GDP and new business formation. Importantly, these results are fully consistent with earlier findings for Germany where two different data sources were used (the micro-census and the business registration statistics, both unable to distinguish between new businesses in different industries, see Fritsch, et al. 2015). In these earlier findings, the two variables also unfold counter-cyclical influences: business formation is higher when unemployment is high, or when GDP is low.

To investigate whether the correlations between the cyclical macroeconomic variables and business formation differ by the four types of the industries, we estimate separate models for these four types (Table 6). Starting with the unemployment rate, we observe only counter-cyclical correlations: high unemployment is positively related to entries into both small and large non-innovative industries, as well as to entries into the innovative large industries, consisting of the high-tech and the technologically advanced manufacturing industries. In contrast, high unemployment does not correlate with the start-up rates in the small innovative industries.

\footnotetext{
${ }^{25}$ While we should emphasize that national cycles also exist, we restrict the analysis to regional cycles, for good reasons: as regional cycles are synchronized to a considerable extent (see Figure A1), the national component is already included in the analysis. Adding data on national cycles would lead to a high degree of multicollinearity. Including variables for the national cycle would also mean that the same variable is regressed on the different outcome variables at the NUTS 2 level, which would reduce the effective number of observations, as only variations over time would then be exploited. Still we cannot exclude that national cycles may have a separate effect (of unknown extent) on region cycles' effects. However, these national cycle effects are beyond the goals of this approach.
} 
Turning to the influence of changes in GDP on start-ups, there is a counter-cyclical relationship between the cyclical component of GDP and start-up rates in all small-scale industries. This holds true for innovative small industries, where knowledge intensive services plus credit and insurance are combined, as well as for all traditional small scale industries, like consumer oriented services.

Thus, when focusing on business entries into the innovative parts of the industries, there is an important difference: the influence of cyclical deviations from unemployment and from GDP levels differ systematically between small-scale and largescale industry types. Changes in unemployment leads to counter-cyclical correlations with the innovative part of the manufacturing industries but not with the innovative part of the small-scale innovative industries. In turn, changes in GDP are correlated with business entries into small-scale innovative industries like the knowledge intensive services. Manufacturing seems to be unaffected by cyclical GDP changes.

The results for the control variables are mostly in accordance with results of previous studies. The share of employees in small businesses has the expected positive sign (if the coefficient is statistically significant) and is particularly relevant for business entries into innovative industries. The variation of the results for the three variables representing distinctive facets of the regional knowledge stock-share of employees with a tertiary degree, number of professors per workforce, and number of patent applications per 1,000 employees-demonstrates differences in the relevant knowledge base for start-ups across industries. Regional knowledge, in particular patents, has a positive influence when focusing on the innovative industries, but also on the non-innovative small industries, pointing to positive externalities of patents on other businesses. A positive, but insignificant, influence is found for the growth rate of the number of professors on entry rates. The effect becomes significantly positive if one considers a threshold for the growth rate: a sufficiently large growth of professors is positively correlated to business entries in most industries (see Table A7).

We should also emphasize that for one variable we observe an unexpected influence: the significantly negative sign for the share of employees with tertiary education on entries into all kinds of small-scaled businesses. ${ }^{26}$ With the exception of this

\footnotetext{
${ }^{26}$ The relatively fixed nature of these variables and the fact that we are using growth rates might explain the counter-intuitive finding with respect to the share of employees with tertiary education.
} 
last result, our findings are consistent with the Knowledge Spillover Theory of Entrepreneurship (Audretsch et al. 2006; Acs, et al. 2009).

Table 6: Influence of cyclical variables on start-ups conditional on the four types

\begin{tabular}{llllll}
\hline Start-up rates in: & All Types & $\begin{array}{l}\text { Type 1: } \\
\text { non-innova- } \\
\text { tive and } \\
\text { small }\end{array}$ & $\begin{array}{l}\text { Type 2: } \\
\text { non-innova- } \\
\text { tive and large }\end{array}$ & $\begin{array}{l}\text { Type 3: } \\
\text { innovative }\end{array}$ & $\begin{array}{l}\text { Type 4: } \\
\text { innovalive } \\
\text { and large }\end{array}$ \\
\hline $\begin{array}{l}\text { Unemployment rate - cyclical } \\
\text { component } t-1\end{array}$ & $0.05^{* * *}$ & $0.08^{* *}$ & $0.10^{* * *}$ & -0.01 & $0.09^{* * *}$ \\
$\begin{array}{l}\text { GDP - cyclical component } \\
t-1\end{array}$ & $-0.17^{* * *}$ & $-0.19^{* * *}$ & -0.03 & $-0.17^{* * *}$ & -0.09 \\
\hline $\begin{array}{l}\text { Share of employees in small } \\
\text { businesses } t-1 \text { (growth) }\end{array}$ & 0.02 & 0.00 & -0.05 & $0.11^{* * *}$ & $0.13^{* * *}$ \\
$\begin{array}{l}\text { Share of employees with ter- } \\
\text { tiary education } t-1 \text { (growth) }\end{array}$ & $-0.08^{* *}$ & $-0.11^{* *}$ & 0.01 & $-0.06^{* *}$ & -0.02 \\
$\begin{array}{l}\text { Number of professors per } \\
\begin{array}{l}1,000 \text { workforce } t-1 \\
\text { (growth) }\end{array}\end{array}$ & 0.03 & 0.03 & 0.02 & 0.03 & 0.03 \\
$\begin{array}{l}\text { Number of patent applica- } \\
\text { tions per 1,000 workforce } t-\end{array}$ & $0.09^{* * *}$ & $0.13^{* * *}$ & 0.01 & $0.07^{* * *}$ & $0.16^{* * *}$ \\
$\begin{array}{l}1 \text { (growth) } \\
\text { Constant }\end{array}$ & $-0.27^{* * *}$ & $-0.62^{* * *}$ & $-0.21^{* * *}$ & $0.36^{* * *}$ & $0.68^{* * *}$ \\
$\mathrm{R}^{2}$ & 0.71 & 0.63 & 0.75 & 0.73 & 0.43 \\
\hline
\end{tabular}

Notes: Fixed effects panel estimates. ${ }^{* * *},{ }^{* *}$ statistically significant at the 1 percent and the 5 percent level, respectively. Business cycle is the cyclical component of the Hodrick-Prescott filtered variables. The remaining independent variables are included in growth rates. All variables are lagged by one period. The number of observations is 494 (38 cross sections, 13 years) in all models. Standard errors are clustered at the region level.

Using Table 6, we obtain the following results with respect to our research questions. In relation to research question 1 , we find that the two cyclical macroeconomic variables influence new business formation in different ways, depending on the size and innovativeness of the business entries.

In relation to research question 2 , we find virtually no correlation that is consistent with a pro-cyclical effect of GDP, as proposed by Rampini (2004), Barlevy (2007), and others. Rather, we observe correlations that are consistent with a counter-cyclical influence of GDP on business entries, but only for entries into all smallscale industries (Type 1 and Type 3), while entries into large-scale industries remain mostly uncorrelated to GDP. Thus, firm size matters for the relationship between the cycle and business entries.

In relation to research question 3, the correlations between unemployment and business entries point to counter-cyclical influences on entries by Type 1 (the small- 
scaled non-innovative businesses, question 3a) while its influence is a-cyclical in industries with a high innovation potential that have small average sizes (Type 3, question $3 b)$. Moreover, correlations between unemployment and business entries also point to counter-cyclical influences on entries into Types 2 and 4, the large-scale industries (question 3c). In summary, there is more of a "size effect," with changes in GDP being related to business entries into small-scale industries, changes in unemployment relating more strongly to entries into large-scale industries, and both relations applying for the innovative parts of these industries.

\subsection{Robustness tests and sensitivity analysis}

We perform several robustness checks and sensitivity tests to examine the robustness of our findings.

\subsubsection{Effect dynamics}

As a first robustness test, we compare the results from the model using one lag (one year) given in equation (6) to a model capturing short-run dynamics of two prior years:

$$
\begin{aligned}
& \text { Startup rate }_{i, t}^{\tau}=\tilde{\mu}_{i}^{\tau}+\alpha_{1,1}^{\tau} \mathrm{BC} \text { unemployment } \\
& +\alpha_{2, t-1}^{\tau} \mathrm{BC} \mathrm{GDP} \\
& i, \alpha_{1,1}
\end{aligned}
$$

where all variables are included with a lag of two periods and with $i=1, \ldots, N$ again being the number of NUTS 2 regions. We are interested in the cumulative correlations of unemployment, $\alpha_{1,1}^{\tau}+\alpha_{1,2}^{\tau}$, and the GDP cycle, $\alpha_{2,1}^{\tau}+\alpha_{2,2}^{\tau}$. Results are provided in Table 7 . We report results for unemployment and GDP. ${ }^{27}$

The results of the analysis with two time lags (Table 7) are consistent with the analysis using only one year (Table 6). The only difference is that there is no correlation between unemployment and start-ups of Type 1 in the distributed lag model, which is because unemployment effects with a lag of one and two periods cancel each other out.

\footnotetext{
${ }^{27}$ Additional results are provided upon request.
} 
Table 7: Short-run dynamics of the influence of cyclical variables on start-ups conditional on the four types

\begin{tabular}{lllll}
\hline Start-up rates in: & $\begin{array}{l}\text { Type 1: } \\
\text { non-innovative } \\
\text { and small }\end{array}$ & $\begin{array}{l}\text { Type 2: } \\
\text { non-innovative } \\
\text { and large }\end{array}$ & $\begin{array}{l}\text { Type 3: } \\
\text { innovative and } \\
\text { small }\end{array}$ & $\begin{array}{l}\text { Type 4: } \\
\text { innovative and } \\
\text { large }\end{array}$ \\
\hline $\begin{array}{l}\text { Unemployment rate }- \text { cyclical } \\
\text { component } t-1\end{array}$ & $0.06^{* *}$ & $0.10^{* * *}$ & -0.01 & $0.07^{* *}$ \\
$\begin{array}{l}\text { Unemployment rate }- \text { cyclical } \\
\text { component } t-2\end{array}$ & $-0.07^{* * *}$ & $0.08^{* * *}$ & -0.04 & 0.02 \\
\hline $\begin{array}{l}\text { GDP }- \text { cyclical component } t-1 \\
\text { GDP }- \text { cyclical component } t-2\end{array}$ & $-0.20^{* * *}$ & -0.06 & $-0.17^{* * *}$ & -0.07 \\
\hline $\begin{array}{l}\text { Cumulative effect of unemploy- } \\
\text { ment }\end{array}$ & -0.01 & 0.01 & 0.01 & 0.03 \\
Cumulative effect of GDP & $-0.18^{* *}$ & $-0.18^{* * *}$ & -0.05 & $0.09^{* * *}$ \\
\hline
\end{tabular}

Notes: Fixed effects panel estimates. ${ }^{* * *}$, ${ }^{* *}$ statistically significant at the 1 percent and the 5 percent level, respectively. Business cycle is the cyclical component of the Hodrick-Prescott filtered variables. The remaining independent variables are included in growth rates. All variables are lagged by two periods. The number of observations is 418 (38 cross sections, 11 years) in all models. Standard errors are clustered at the region level.

\subsubsection{Industry GDP cycles}

As we argue that entrepreneurship is a regional phenomenon, we only consider how the business cycle at the regional level influences firm entries in the same region. However, we cannot exclude that demand conditions in the sector in which the firm intends to start unfold influences on business entries that are different from those of the regional cycle. Therefore, we test to what extent the gross value added cycle in a specific industry is relevant when explaining start-up rates. We add the industry specific gross value added to Equation (6) and estimate the following model:

$$
\text { Startup rate } \begin{aligned}
{ }_{i, t}^{\tau}= & \mu_{i}^{\tau}+\alpha_{1}^{\tau} \text { BC unemployment } \\
& \alpha_{3}^{\tau} \mathrm{BC} \mathrm{GVA}_{i, t-1}+\boldsymbol{\eta}_{\tau}^{\top} \mathbf{x}_{i, t-1}+u_{i, t}^{\tau}
\end{aligned}
$$

where $\mathrm{BC} \mathrm{GVA}_{i, t-1}$ represents the cyclical component of the (production) gross value added sorted by the four types of industries in the same region lagged by one year. The GVA cycle is computed with the same method as the GDP and unemployment cycle. $i=1, \ldots, N$ is again the index of NUTS 2 regions.

Comparing the outcomes of Table 8 with Table 6 , we observe that the coefficients only marginally change. The significant correlations remain the same, i.e. changes in GDP are counter-cyclically related to entries in small industries, while changes in unemployment rates are counter-cyclically related to entries in all industries except for entries of small innovative businesses. 
Table 8: Influence of cyclical variables on start-ups conditional on the four types with controls for industry-specific cycles

\begin{tabular}{|c|c|c|c|c|}
\hline Start-up rates in: & $\begin{array}{l}\text { Type 1: } \\
\text { non-innova- } \\
\text { tive and small }\end{array}$ & $\begin{array}{l}\text { Type 2: } \\
\text { non-innova- } \\
\text { I tive and large }\end{array}$ & $\begin{array}{l}\text { Type 3: } \\
\text { innovative and } \\
\text { small }\end{array}$ & $\begin{array}{l}\text { Type 4: } \\
\text { innovative and } \\
\text { large }\end{array}$ \\
\hline $\begin{array}{l}\text { Unemployment rate - cyclical compo- } \\
\text { nent } t-1\end{array}$ & $0.08^{* *}$ & $0.10^{\star * *}$ & -0.02 & $0.07^{* *}$ \\
\hline GDP - cyclical component $t-1$ & $-0.19^{* * *}$ & -0.03 & $-0.16^{\star \star *}$ & -0.04 \\
\hline Type-specific GVA - cyclical $t-1$ & 0.02 & 0.01 & -0.03 & $-0.08^{* * *}$ \\
\hline $\begin{array}{l}\text { Share of employees in small busi- } \\
\text { nesses } t-1 \text { (growth) }\end{array}$ & 0.01 & -0.05 & $0.11^{* * *}$ & $0.13^{* * *}$ \\
\hline $\begin{array}{l}\text { Share of employees with tertiary edu- } \\
\text { cation } t-1 \text { (growth) }\end{array}$ & $-0.11^{* *}$ & 0.01 & -0.05 & -0.03 \\
\hline $\begin{array}{l}\text { Number of professors per } 1,000 \text { work- } \\
\text { force } t-1 \text { (growth) }\end{array}$ & 0.03 & 0.03 & 0.03 & 0.03 \\
\hline $\begin{array}{l}\text { Number of patent applications per } \\
1,000 \text { workforce } t-1 \text { (growth) }\end{array}$ & $0.13^{* * *}$ & 0.01 & $0.07^{* \star *}$ & $0.16^{* * *}$ \\
\hline Constant & $-0.62^{* \star *}$ & $-0.21^{* \star *}$ & $0.35^{\star \star *}$ & $0.69^{* * *}$ \\
\hline $\mathrm{R}^{2}$ & 0.63 & 0.75 & 0.73 & 0.44 \\
\hline
\end{tabular}

Notes: Fixed effects panel estimates. ${ }^{* * *}$, ${ }^{* *}$ statistically significant at the 1 percent and the 5 percent level, respectively. Business cycle is the cyclical component of the Hodrick-Prescott filtered variables. The remaining independent variables are included in growth rates. All variables are lagged by one period. The number of observations is 494 (38 cross sections, 13 years) in all models. Standard errors are clustered at the region level.

The industry cycle unfolds only a counter-cyclical influence on entries of large innovative firms. All other industries remain unaffected by changes in the industry cycle; i.e. the relationship between the regional gross value added and entries of small firms as well as of non-innovative large firms is a-cyclical. Overall, these results indicate that even if industry-specific demand conditions differ from the regional cycle, they still unfold a counter-cyclical effect.

\subsubsection{Potential endogeneity bias}

Consider the following model for business entry:

$$
\text { Entry }=v \text { Business cycle variable }+b Y+\epsilon_{1}
$$

where indices (such as the time index) are dropped for notational convenience. The variable $Y$ includes $\mathbf{x}$ control variables, a constant, region fixed effects, and potentially additional variables. As we are interested in the influence of the business cycle, $v$ is the coefficient of interest. The OLS estimate of $v$ is unbiased if the business cycle 
variable and the error $\epsilon_{1}$ are not correlated. Since we include all business cycle variables in lags, the likelihood of such a correlation is small. However, to examine whether results are robust to relaxing the assumption of exogeneity, we perform several instrumental-variable-based checks.

To examine a plausible mechanism generating correlation between the business cycle variable and the error, consider the following model for the business cycle:

$$
\text { Business cycle variable }=c Y+\epsilon_{2}
$$

If $\epsilon_{1}$ and $\epsilon_{2}$ are correlated, OLS estimates of $v$ will be biased. This might happen if, for instance, there is an unobserved variable $U$ driving business cycle and entry at the same time, i.e. $\epsilon_{1}=U+\breve{\epsilon}_{1}$ and $\epsilon_{2}=d U+\breve{\epsilon}_{2}$, where $\breve{\epsilon}_{1}$ and $\breve{\epsilon}_{2}$ are idiosyncratic errors. We try to account for potential endogeneity by applying the instrumental-variable method. In the given setting, we need an instrument for the unemployment and GDP cycle, which enters (10) but not (9).

A reasonable instrument for unemployment is the implementation of one of the so-called Hartz labor market reforms at the beginning of the year 2005. Before this reform, non-employed individuals receiving social welfare were not required to be available to the labor market. After its implementation, individuals receiving the new form of unemployment benefits (instead of social welfare) were required to be available to the labor market. While the reform was implemented on January 1, 2005, it generated incentives for individuals receiving social welfare to register as unemployed beginning in 2004, as the unemployment benefits were higher than social welfare payments. ${ }^{28}$ As registering as unemployed required availability to the labor market, the reform resulted in an increase in unemployment without directly affecting start-up incentives in 2004. A fact that might weaken the exclusion restriction is that an earlier part of the reform was a start-up subsidy for entrepreneurship out of unemployment, the so-called "Ich-AG." However, that subsidy started January 1, 2003, some two years earlier. Furthermore, we test whether the subsidy might influence results by removing all types of services from small scale businesses, as this is the most common type of start-ups from unemployment (Caliendo and Kritikos 2010), and obtained similar results. ${ }^{29}$

\footnotetext{
${ }^{28}$ See German newspaper reports from this period; for instance, Spiegel 2005.

${ }^{29}$ Results are available on request.
} 
An instrument for the GDP cycle is the pre-crisis peak in 2007. As the German economy is highly export-oriented, it was affected by the pre-crisis boom in the US through trade links. As in the pre-crisis period US GDP and, through the trade channel, then German GDP were pushed above the trend by forces not directly related to the German economy, the pre-crisis boom is a candidate for a valid instrument. The beginning of the financial crisis in the US in 2008, where this year constitutes the last observation in the analysis period, might have affected start-ups through the finance channel. ${ }^{30}$ To control for this channel, in an additional regression we remove banking industry start-ups and include them as a covariate, approximating the health of this industry.

Table 9: Influence of the unemployment and GDP cycle on start-ups conditional on size given that the unemployment or GDP cycles are instrumented

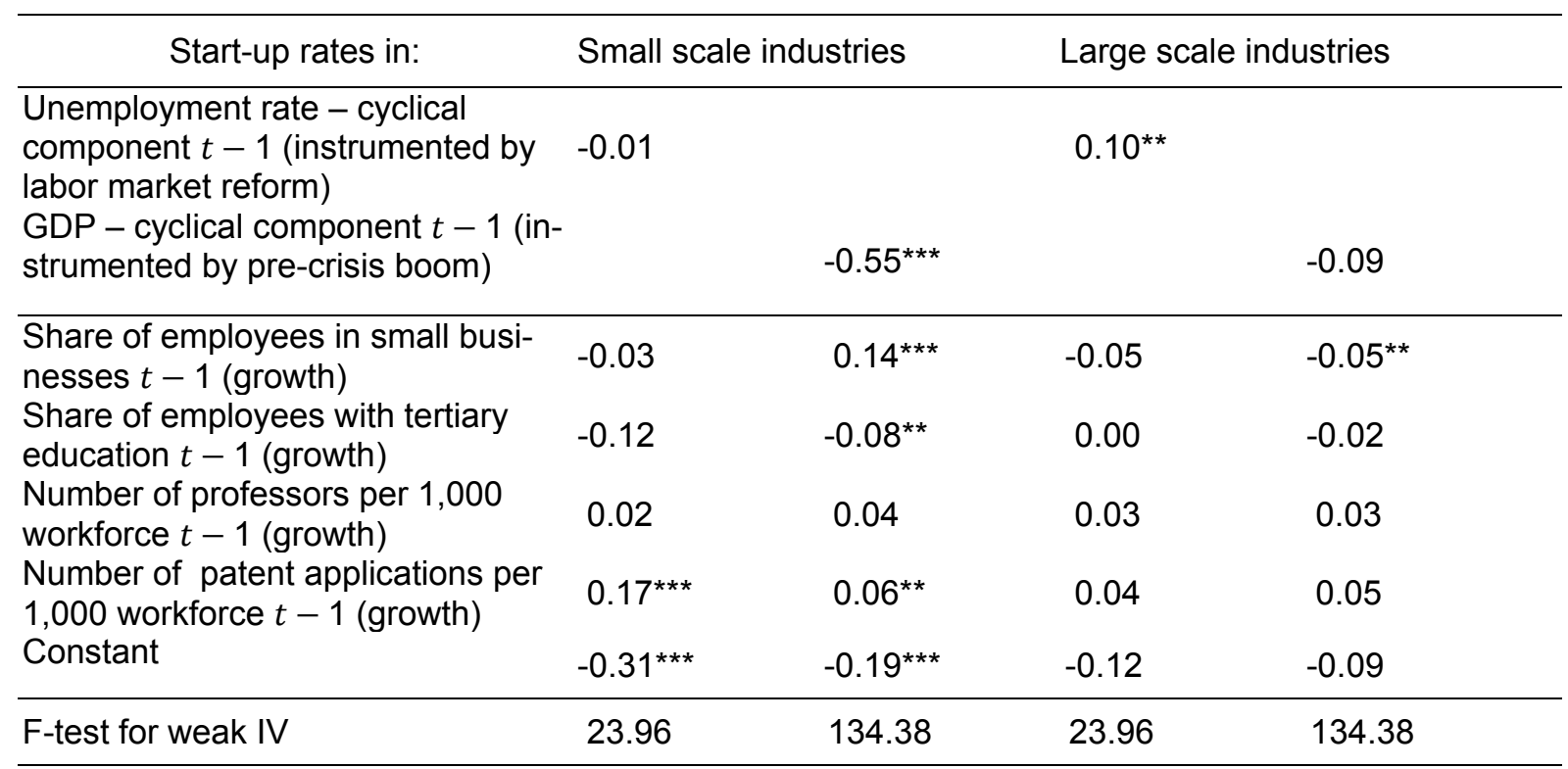

Notes: ${ }^{* * *},{ }^{* *}$ statistically significant at the 1 percent and the 5 percent level, respectively; IV estimation with fixed effects; business cycle is the cyclical component of the Hodrick-Prescott filtered variables. The remaining independent variables are included in growth rates. All variables are lagged by one period. The number of observations is 494 (38 cross sections, 13 years) in all models. Standard errors are clustered at the region level.

We estimate separate models for the effects of unemployment and GDP using two-stage least squares. Since the approach removes variance from the cyclical variables, as the instruments are effectively time dummies, and there is less variance in case of Type-4 entries (Figure 2), we aggregate the types and consider only effects

\footnotetext{
30 Unemployment rates in Germany were almost unaffected by the beginning of the financial crisis and remained almost unchanged throughout the course of the crisis—-the so-called "German miracle;" see also Burda and Hunt (2011).
} 
on small- and large-scale industries. First stages are presented in Tables A8 (unemployment) and A9 (GDP) in Appendix A. Table 9 shows results of second stage regressions. The instruments have sufficient strength (see the F-test in Table 9). In line with previous results, entry into small-scale industries is mostly counter-cyclically influenced by GDP, whereas entry into large-scale industries is mostly counter-cyclically influenced by unemployment. Table A10 in the Appendix provides the results when banking is removed from small-scale industries and entries into banking are included as an additional covariate. Results are consistent with Table 9, although the size of the GDP cycle effect on entries into small-scale industries is smaller.

Models using the two instruments are exactly identified such that instrument validity cannot be tested. However, if certain conditions are met, it is possible to construct additional instruments in order to be able to perform a Sargan-Hansen test. Let the structural system be given by (9) and (10). In this case, the instrumental variable approach proposed by Lewbel (2012) demonstrates that, by exploiting potential heteroskedasticity in the error term in (10), it is possible to consistently estimate effects without an available exclusion restriction if certain assumptions hold. Let $Z$ denote a set of variables that are exogenous and that affect start-ups and the business cycle variable, i.e. they are part of (9) and (10). $Z$ can include some or all elements of $Y$. In addition to the standard conditions, viz. $\mathbb{E}\left[Y \epsilon_{1}\right]=0, \mathbb{E}\left[Y \epsilon_{2}\right]=0$, and $\mathbb{E}\left[Y Y^{\top}\right]$ is nonsingular, the approach of Lewbel (2012), which we refer to as Lewbel IV, requires that $\operatorname{Cov}\left(Z, \epsilon_{1} \epsilon_{2}\right)=0$ and $\operatorname{Cov}\left(Z, \epsilon_{2}^{2}\right) \neq 0$. If the conditions hold, $(Z-\bar{Z}) \epsilon_{2}$ is a valid instrument for the business cycle variable, where $\bar{Z}$ is the sample average of $Z$. If $\operatorname{Cov}\left(Z, \epsilon_{2}^{2}\right) \neq 0$ does not hold, the instrument will be weak (Lewbel 2012) such that testing for instrument strength indirectly tests for the assumption.

To construct the instrument, we assume that $Z$ includes the share of employees in small businesses, the share of employees with tertiary education, and the number of patent applications. The selection is based on the criterion of sufficient instrument strength. Using $Z$ constructed in such a way, we test if the errors in Equation (10) are heteroskedastic, a test if $\operatorname{Cov}\left(Z, \epsilon_{2}^{2}\right) \neq 0$ holds, could reject homoskedasticity at the $5 \%$ level using a Breusch-Pagan test. 
Table 10: Influence of the unemployment and GDP cycle on start-ups conditional on size given that effects are estimated with a combination of Lewbel IV and traditional IV

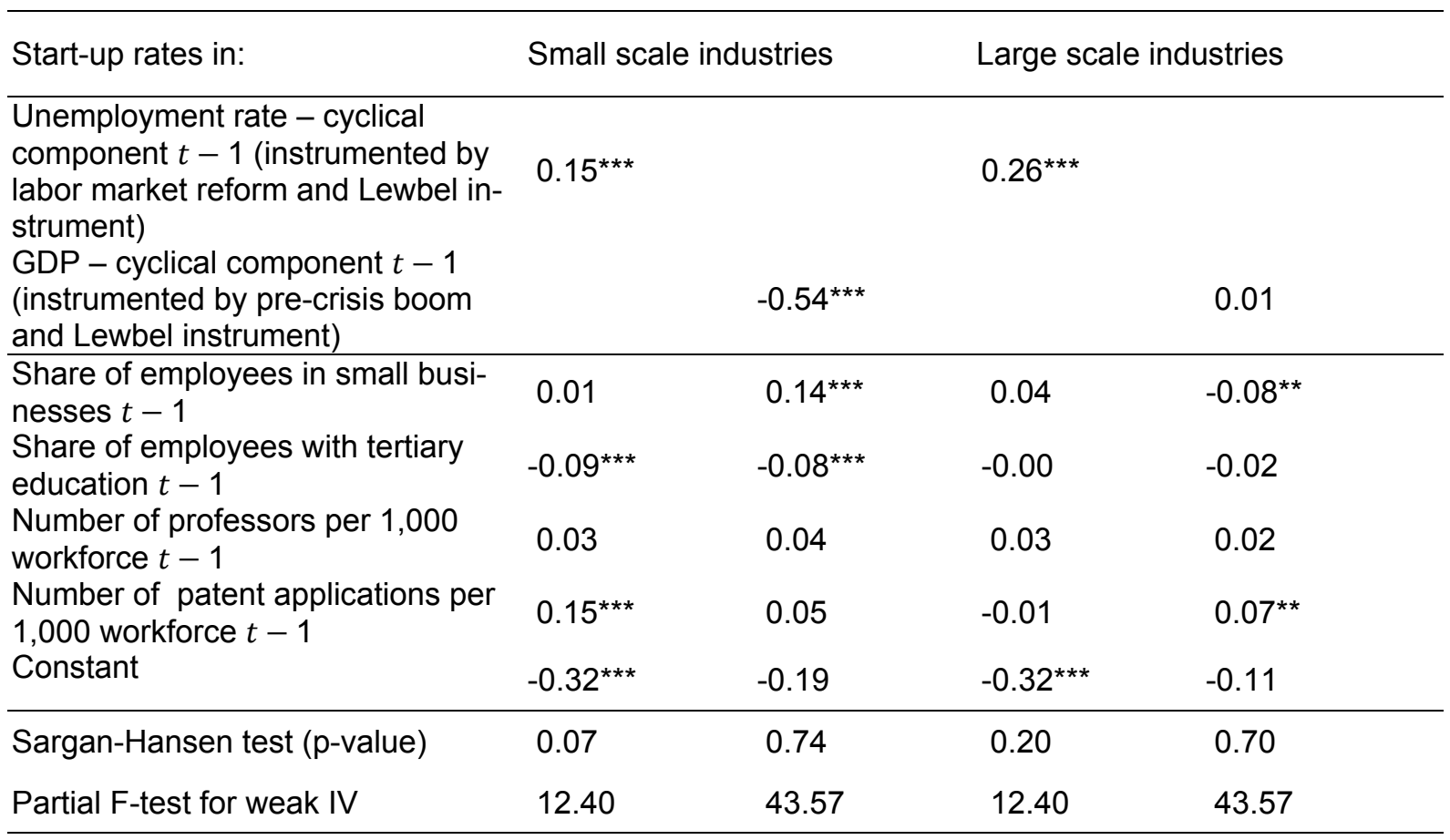

Notes: ${ }^{* * *}$, ${ }^{* *}$ statistically significant at the 1 percent and the 5 percent level, respectively; IV-GMM estimation with fixed effects; business cycle is the cyclical component of the Hodrick-Prescott filtered variables. The remaining independent variables are included in growth rates. All variables are lagged by one period. The number of observations is 494 (38 cross sections, 13 years) in all models. Standard errors are heteroskedasticity robust.

Thus, we do not find violations of the Lewbel (2012) conditions for instrument construction. Lewbel (2012) instruments are combined with the instruments we already used for unemployment and GDP, with the model, which is now over-identified, estimated using IV-GMM. Results are presented in Table 10. The F-test results at the first stage (see Table 10) suggest that the generated instruments are not weak. Results show that there is no significant counter-cyclical influence of unemployment on entries into small-scale industries, but entries into these type of industries are still counter-cyclically influenced by GDP. In case of large-scale industries, the only statistically significant business cycle effect is a counter-cyclical influence of unemployment. Hence, results are consistent with previous estimation results.

As the system is now over-identified, we perform a Sargan-Hansen test to examine whether the exclusion restriction for the 2004-reform and the 2007-pre-crisispeak instruments does not hold. The hypothesis that overidentifying restrictions are valid cannot be rejected at the $5 \%$ level (Table 10), suggesting that the instruments are valid (conditional on validity of the Lewbel instruments). 


\subsubsection{Aggregation}

Another issue could be that the aggregation of data to a specific type of industry poses a limitation. So far, we numerically added up all start-up rates for each type of industry, as in the existing literature that focuses on total start-ups over all industries. This procedure might give greater weight to industries with higher start-up rates, which do not necessarily have the same weight in terms of industry GDP. Countercyclical results might then be driven by industries with small economic relevance, while industries with high economic relevance, as measured by their gross value added, might not exhibit counter-cyclical effects. Therefore, as a sensitivity check, we aggregate start-ups considering their weight in industry GDP. We restrict our analysis to industries of different sizes, as weights are more robust at this level and we mostly found size effects in the previous analysis.

Table 11: Influence of cyclical variables on start-ups conditional on size with valueadded based entry weights

\begin{tabular}{lll}
\hline Unemployment rate - cyclical component $t-$ & 0.03 & $0.09^{\star * *}$ \\
1 & & \\
GDP - cyclical component $t-1$ & $-0.23^{* * *}$ & $-0.08^{* * *}$
\end{tabular}

\begin{tabular}{lll}
\hline $\begin{array}{l}\text { Share of employees in small businesses } t-1 \\
\text { (growth) }\end{array}$ & 0.07 & -0.01 \\
$\begin{array}{l}\text { Share of employees with tertiary education } \\
t-1 \text { (growth) }\end{array}$ & $-0.11^{* *}$ & -0.03 \\
$\begin{array}{l}\text { Number of professors per 1,000 workforce } \\
t-1 \text { (growth) }\end{array}$ & 0.04 & 0.01 \\
$\begin{array}{l}\text { Number of patent applications per 1,000 } \\
\text { workforce } t-1 \text { (growth) }\end{array}$ & $0.16^{* * *}$ & 0.04 \\
$\begin{array}{l}\text { Constant } \\
\mathrm{R}^{2}\end{array}$ & $-0.36^{* * *}$ & $-0.04^{* * *}$ \\
\hline
\end{tabular}

Notes: Fixed effects panel estimates. ${ }^{* * *}$, ${ }^{* *}$ statistically significant at the 1 percent and the 5 percent level, respectively. Business cycle is the cyclical component of the Hodrick-Prescott filtered variables. The remaining independent variables are included in growth rates. All variables are lagged by one period. The number of observations is 494 (38 cross sections, 13 years) in all models. Standard errors are clustered at the region level.

Similar to previous results, see for instance Table 8, we observe in Table 11 that entries into small-scale industries are counter-cyclically influenced by GDP, but the effect of unemployment is a-cyclical. Entries into large-scale industries are counter-cyclically influenced by unemployment and GDP. Hence, even when weighting entries by their economic importance, effects are still counter-cyclical. 


\subsubsection{Detrending technique}

An open concern is that results might be driven by the detrending technique. The Hodrick-Prescott filter has a free parameter, set by the user of the procedure and not driven by data that might influence results (Schlicht 2005). Furthermore, the filter has an end-point bias (Mise, Kim and Newbold 2005). Therefore, to check the robustness of the results, we use an alternative filter, developed by Baxter and King (1999). The Baxter-King filter, isolating the cyclical component from the trend, was explicitly designed to overcome the limitations of the Hodrick-Prescott filter.

In line with the recommendations of Baxter and King (1999) for annual data, the minimum period of oscillation is set to 2 and the maximum to 8 , while the order of the filter is 3. Results are provided in Table A11 in the Appendix. Nearly all results under the Baxter-King filter are consistent with those from the Hodrick-Prescott filter. The only exception is the correlation between unemployment and entries by Type 4, which is now a-cyclical, instead of counter-cyclical, when using the Baxter-King filter. This could be a result of the end-point bias of the Hodrick-Prescott filter. However, as results obtained using the Baxter-King filter are numerically similar to results in Table 6 for the remaining three types, it is more likely that the statistical insignificance results from the fact that the Baxter-King filter removes around 80 data points (data at the beginning and end of each time series in each region).

\subsubsection{Unobserved spatial links between regions}

Studies examining the connection between the business cycle and business entries usually do not account for unobserved spatial links. For instance, Köllinger and Thurik (2012) use a country level panel and control for country fixed effects, but do not control for unobserved dependencies between countries. However, previous studies demonstrate that German municipalities compete on taxes (Büttner 2001), spending (Borck, et al. 2007), and debt (Borck, et al. 2015). This type of competition is unobserved in our model and would enter it through the error term. To test whether our results are sensitive to including unobserved spatial dependencies, we estimate a spatial error model with spatial fixed effects (see Appendix B).

The results of this estimation (Table B1, Appendix B) are consistent with previous results, confirming counter-cyclicality of both macro-economic variables. The only difference compared to Table 6 is that the correlation between unemployment 
and Type-1 entries is insignificant after introducing spatial dependencies. Thus, with spatial dependencies, the difference between small and large businesses becomes more pronounced, similar to the result when we investigate effect dynamics with two lags. Entries into small-scale businesses react counter-cyclically to GDP and a-cyclically to unemployment, while entries into large-scale businesses mostly react counter-cyclically to unemployment and a-cyclically to GDP (Table B1 in Appendix B). ${ }^{31}$

\section{Summary and conclusions}

While nearly all existing empirical analyses of how the business cycle affects business venturing examine start-ups in the total private sector, our study systematically distinguishes between start-ups in four different types of industries. We find distinct variations in how variables that represent the business cycle are correlated with new firm formation across industries. Our analysis with data for German NUTS 2 regions reveals correlations that are consistent with counter-cyclical effects of the business cycle on entries into the market, either more businesses are started when unemployment is high or when GDP is low. Moreover, correlations differ more between largeand small-scale industries than between innovative and non-innovative industries in the sense that entries into large-scale industries are mainly influenced by variations in unemployment, while entries into small-scale industries are affected by variations in GDP. Results are robust to applying different model specifications. Thus, these results indicate that the industry context that stands for demand conditions, technologies, production methods, and cost structures matters quite significantly.

It is remarkable that in no industry is a GDP level above the trend correlated with increasing entries. Although causal interpretations are only to a certain extent possible given the constraint set, this observation suggests that favorable conditions in terms of high GDP might not be germane for start-ups. In fact, according to our results, it is the other way around: an economic downturn, maybe in the sense of lower production cost or entry costs, seems to be a more favorable environment for innovative businesses than boom periods. This holds at least for entries of small-scale businesses, while entries of large-scale businesses are uncorrelated to changes in GDP.

\footnotetext{
${ }^{31}$ As further robustness checks, we run the models for low-density and high-density regions as well as for East and West Germany separately. However, we do not find significant differences between these spatial categories.
} 
We further interpret our second result-the positive correlations between unemployment and entries of large-scaled businesses-as an indicator that these entries are influenced by easier availability of labor when unemployment is high. However, this does not necessarily mean that newly-founded large-scaled innovative businesses start hiring unemployed workers - they may simply hunt for workers who are employed else but may be willing to change jobs at a lower mobility wage premium. Nevertheless, overall this might give the labor market an upward push in the short-term while in the medium-term such positive effects could be overcompensated by lay-offs of incumbents who might be driven out of the market (see also footnote 5).

We should also emphasize that we did not find such correlations between high unemployment and entries in industries that are commonly assumed to provide a well-suited environment for an unemployment push effect for necessity entrepreneurs, namely for start-ups in small-scaled non-innovative industries, . All together, these results contrast with earlier research (see Ghatak et al. 2007; Köllinger and Thurik 2012; Roman et al. 2013) that did not distinguish between entries into different industries but assumed that opportunity driven start-ups should be expected more frequently during boom periods.

Our findings demonstrate the importance of accounting for industry-specific characteristics when analyzing the relationship between the business cycle and new business formation. Since empirical research has hardly investigated to what extent the business cycle has differing effects on new business formation in different industries, more research on this topic is needed. It would be desirable to have similar studies for other countries, particularly for countries like the US where overall pro-cyclical effects seem to prevail. It is important to understand why in some countries procyclical and in other countries counter-cyclical influences predominate. Is it that in some countries supply-side effects, such as production cost, influence entry decisions more strongly while in other countries it is the demand side? Or do profit expectations during boom periods and recession differ between countries?

Since new businesses, especially innovative start-ups, may have a positive effect on economic development (Acs et al. 2009; Fritsch 2013; Kritikos 2014), they might play a crucial role in reducing effects of aggregate economic shocks and supporting economic recovery. Hence, it is also important to analyze how cycle-induced entries affect economic development. Again, empirical analysis for the US points to 
opposing results. While Lee and Mukoyama (2015) find, for the US manufacturing sector, that firms opened during recessions start with about $30 \%$ more employees than firms opened during boom periods, Sedlácek and Sterk (2017), analyzing entries into all industries, find the opposite, namely more job creation in firms opened during boom periods. Therefore, it is important to have data that comprise more information about the characteristics of the new businesses in each of these industries, such as their size, the timing and the amount of innovation efforts, as well as the timing of the commercialization of innovative ideas. Such data could allow for a more precise identification of different types of new ventures and, thus, for causal interpretations of the results.

Moreover, in the present paper we do not perform separate analyses for boom and recession periods. Thus, future research may investigate to what extent booms and recessions unfold differing influences in terms of intensity and direction, as we cannot exclude that there are asymmetric effects of cycling changes on business entries. Similarly, we have only analyzed the influence of 'regular' recessions on entries. Thus, it is important to reveal whether the effect directions differ between recessions and depressions, as in the aftermath of the 2008 financial crisis. Existing research on this question finds again diverging results, but only for the total number of start-ups (see Siemer 2014, or Hundt and Sternberg 2014). To these ends, more empirical research on business cycle effects on new business formation is needed. 


\section{Literature}

Acs, Zoltan J., Pontus Braunerhjelm, David B. Audretsch and Bo Carlsson (2009): The Knowledge Spillover Theory of Entrepreneurship. Small Business Economics, 32, 15-30.

Åstebro, Thomas, Braunerhjelm, Pontus and Anders Broström (2013): Does Academic Entrepreneurship Pay? Industrial and Corporate Change, 22, 281-311.

Audretsch, David, B. (1995): Innovation and Industry Evolution. Cambridge (MA): MIT Press.

Audretsch, David, B. Max C. Keilbach and Erik Lehmann (2006): Entrepreneurship and Economic Growth. Oxford: Oxford University Press.

Barlevy, Gadi (2007): On the Cyclicality of Research and Development. American Economic Review, 97, 1131-1164.

Baxter, Marianne and Robert G. King (1999): Measuring Business Cycles: Approximate Band-Pass Filters for Economic Time Series. Review of Economics and Statistics, 81, 575-593.

Bernanke, Ben, and Mark Gertler (1989): Agency Costs, Net Worth, and Business Fluctuations. American Economic Review, 79, 14-31.

Bersch, Johannes, Sandra Gottschalk, Bettina Müller and Michaela Niefert (2014): The Mannheim Enterprise Panel (MUP) and Firm Statistics for Germany. Mannheim: ZEW (ZEW Discussion Paper No. 14-104).

Büttner, Thiess (2001): Local Business Taxation and Competition for Capital: The Choice of the Tax Rate, Regional Science and Urban Economics, 31, 215245.

Borck, Rainald, Marco Caliendo and Viktor Steiner (2007): Fiscal Competition and the Composition of Public Spending: Theory and Evidence, Public Finance Analysis, 63, 264-277.

Borck, Rainald, Frank M. Fossen, Ronny Freier and Thorsten Martin (2015): Race to the Debt Trap? Regional Science and Urban Economics, 53, 20-37.

Breitung, Jörg (2000): The Local Power of some Unit Root Tests for Panel Data. In Advances in Econometrics, Vol. 15: Nonstationary Panels, Panel Cointegration, and Dynamic Panels, 161-178. Amsterdam: JAI, Press.

Burda, Michael C. and Jennifer Hunt (2011): What explains the German Labor Market Miracle in the Great Recession? Brookings Papers on Economic Activity, Spring, 2011, 273-319.

Caballero, Ricardo J. and Mohamad L. Hammour (1994): The Cleansing Effect of Recessions. American Economic Review, 84, 1350-1368.

Caliendo, Marco and Alexander S. Kritikos (2010): Start-ups by the Unemployed: Characteristics, Survival and Direct Employment Effects. Small Business Economics, 35, 71-92. 
Carree, Michael A. and A. Roy Thurik (2008): The Lag Structure of the Impact of Business Ownership on Economic Performance in OECD Countries. Small Business Economics, 30, 101-110.

Clementi, Gian L. and Berardino Palazzo (2016): Entry, Exit, Firm Dynamics and Aggregate Fluctuations. American Economic Journal: Macroeconomics, 8, 1-41.

Congregado, Emilio, Antonio A. Golpe, and Simon C., Parker (2012): The Dynamics of Entrepreneurship: Hysterisis, Business Cycles and Government Policy. Empirical Economics, 43, 1239-1261.

Elfenbein, Daniel W., Barton H. Hamilton and Todd R. Zenger (2010): The Small Firm Effect and the Entrepreneurial Spawning of Scientists and Engineers. Management Science, 56, 659-681.

Elhorst, J. Paul (2003): Specification and Estimation of Spatial Panel Data Models. International Regional Sciences Review, 26, 244-268.

Fairlie, Rob W. (2013): Entrepreneurship, Economic Conditions, and the Great Recession. Journal of Economics \& Management Strategy, 22, 207-231.

Foti, Alessandro and Marco Vivarelli (1994): An Econometric Test of the Self-employment Model-the Case of Italy. Small Business Economics, 6, 81-93.

Francois, Patrick and Huw Lloyd-Ellis (2003): Animal Spirits Through Creative Destruction. American Economic Review, 93, 530-550.

Fritsch, Michael (2013): New Business Formation and Regional Development-A Survey and Assessment of the Evidence. Foundations and Trends in Entrepreneurship, 9, 249-364.

Fritsch, Michael and Ronney Aamoucke (2017): Fields of Knowledge in Higher Education Institutions, and Innovative Start-Ups-An Empirical Investigation. Papers in Regional Science, 96, S1-S27.

Fritsch, Michael, Alexander Kritikos and Katharina Pijnenburg (2015): Business Cycles, Unemployment and Entrepreneurial Entry - First Evidence from Germany. International Entrepreneurship and Management Journal, 11, 267-286.

Fritsch, Michael, Alexander Kritikos and Alina Rusakova (2012): Who starts a business and who is self-employed, IZA Disc. Paper No 6326.

Gehrke, Birgit, Rainer Frietsch, Peter Neuhäusler und Christian Rammer (2013), Neuabgrenzung forschungsintensiver Industrien und Güter [New classification of research intensive industries and products]. NIW/ISI/ZEW-Listen 2012, Studien zum deutschen Innovationssystem, Nr. 8-2013, Berlin.

Georgellis, Yannis and Howard J. Wall (2000): What Makes a Region Entrepreneurial? Evidence from Britain. Annals of Regional Science, 34, 385-403.

Ghatak, Maitreesh, Massimo Morelli and Tomas Sjöström (2007): Entrepreneurial Income, Occupational Choice, and Trickle-up Policies. Journal of Economic Theory, 137, 27-48.

Glaeser, Edward L., William R. Kerr, and Giacomo A.M. Ponzetto (2010): Clusters of Entrepreneurship, Journal of Urban Economics 67, 150-168. 
Hodrick, Robert J. and Edward C. Prescott (1997): Postwar U.S. Business Cycles: An Empirical Investigation. Journal of Money, Credit and Banking, 29, 1-16.

Holmes, Thomas J. and James A. Schmitz, Jr. (1990): A Theory of Entrepreneurship and Its Application to the Study of Business Transfers. Journal of Political Economy, 98, 265-294.

Hopenhayn, Hugo A. (1992): Entry, Exit, and Firm Dynamics in Long Run Equilibrium. Econometrica, 60, 1127-1150.

Hundt, Christian and Rolf Sternberg (2014): How Did the Economic Crisis Influence New Firm Creation? Journal of Economics and Statistics, 234, 722-756.

Hundt, Christian and Rolf Sternberg (2016): Explaining New Firm Creation in Europe from a Spatial and Time Perspective: A Multilevel Analysis based upon Data of Individuals, Regions and Countries. Papers in Regional Science, 95, 223-257.

Koellinger, Philipp and Roy Thurik (2012): Entrepreneurship and the Business Cycle. Review of Economics and Statistics, 94, 1143-1156.

Kritikos, Alexander (2014): Entrepreneurs and their Impact on Jobs and Economic Growth, IZA World of Labor, 8 (May).

Lee, Yoonsoo and Toshihiko Mukoyama (2015): Entry and Exit of Manufacturing Plants over the Business Cycle. European Economic Review, 77, 20-27.

Lewbel, Arthur (2012): Using Heteroscedasticity to Identify and Estimate Mismeasured and Endogenous Regressor Models, Journal of Business and Economic Statistics, 30, 67-80.

Lewis, Vivien. (2009): Business Cycle Evidence on Firm Entry, Macroeconomic Dynamics 13, 605-624.

Mise, Emi, Tae-Hwan Kim, and Paul Newbold (2005): On Suboptimality of the Hodrick-Prescott Filter at Time Series Endpoints. Journal of Macroeconomics, 27, 53-67.

Montoya, Lourdes A. and Jakob de Haan (2008): Regional Business Cycle Synchronization in Europe? International Economics and Economic Policy, 5, 123137.

Mortensen, Dale T. and Christopher A. Pissarides. (1994): Job creation and job destruction in the theory of unemployment. Review of Economic Studies, 61, 397-415.

Organization for Economic Co- operation and Development (OECD) (2005): OECD Handbook on Economic Globalization Indicators. Paris: OECD.

Parker, Simon C. (2009): Why do small firms produce the entrepreneurs? Journal of Socio-Economics, 38, 484-494.

Parker, Simon C. (2012a): The Economics of Entrepreneurship. Cambridge: Cambridge University Press.

Parker, Simon C. (2012b): Theories of Entrepreneurship, Innovation and the Business Cycle. Journal of Economic Surveys, 26, 377-394. 
Parker, Simon C., Emilio Congregado, Antonio A. Golpe (2012): Is Entrepreneurship a Leading or a Lagging Indicator of the Business Cycle. International Small Business Journal, 30(7), 736-753.

Rampini, Adriano A. (2004): Entrepreneurial Activity, Risk, and the Business Cycle. Journal of Monetary Economics, 51, 555-573.

Ravn, Morten O. and Harald Uhlig (2002): On Adjusting the Hodrick-Prescott Filter for the Frequency of Observations. The Review of Economics and Statistics, 84, 371-376.

Robson, Martin T. (1998): Self-Employment in the UK Regions, Applied Economics 30, 313-322.

Román, Concepción, Emilio Congregado and José M. Millán (2013): Start-up Incentives: Entrepreneurship Policy or Active Labour Market Programme? Journal of Business Venturing, 28, 151-175.

Sanchis Llopis, Juan A., José María Millán, Rui Baptista, Andrew Burke, Simon C. Parker and Roy Thurik (2015): Good Times, Bad Times: Entrepreneurship and the Business Cycle. International Entrepreneurship and Management Journal, 11, 243-251.

Schlicht, Ekkehart (2005): Estimating the Smoothing Parameter in the So-called Hodrick-Prescott Filter. Journal of Japanese Statistical Society, 35, 99-119.

Sedlácek, Petr and Vincent Sterk (2017): The Growht Potential of Startups over the Business Cycle. Forthcoming in the American Economic Review.

Shane, Scott (2001): Technology Regimes and New Firm Formation. Management Science 47, 1173-1181.

Siemer, Michael (2014): Firm Entry and Employment Dynamics in the Great Recession. FEDS Disc. Paper 2014-56.

Spengler, Anja (2008): The Establishment History Panel. Schmollers Jahrbuch / Journal of Applied Social Science Studies, 128, 501-509.

Spiegel (2005, January 4): Höchste Jahresarbeitslosigkeit seit der Wiedervereinigung. Der Spiegel. Retrieved from http://www.spiegel.de

Statistisches Bundesamt a (various volumes): Volkswirtschaftliche Gesamtrechnung der Länder. Wiesbaden: Statistisches Bundesamt. http://www.vgrdl.de/VGRdL/tbls/home.asp?lang=en-GB

Statistisches Bundesamt b (various volumes): Fachserie 11 - Bildung und Kultur. Wiesbaden: Statistisches Bundesamt.

Thurik, A.Roy, Martin A. Carree, André van Stel, and David A. Audretsch, (2008): Does Self-Employment Reduce Unemployment? Journal of Business Venturing, 23, 673-686.

Van Stel, André, Martin A. Carree, and A. Roy Thurik (2005): The Effect of Entrepreneurial Activity on National Economic Growth. Small Business Economics, 24, 311-321. 


\section{Appendix A: Data Characteristics and Robustness Checks}

\section{Table A1: Classification of industries}

\begin{tabular}{ll}
\hline Industry & Industry codes (NACE 1993) \\
\hline All private industries & $10-93$ (without 91$)$ \\
Energy and mining & $10,11,12,13,14,40,41$ \\
Manufacturing & $15-37$ \\
High-tech manufacturing industries & $23.30,24.20,24.41,24.61,29.11,29.60,30.02$, \\
& $31.62,32.10,32.20,33.20,33.30,35.30$ \\
& $22.33,24.11,24.12,24.13,24.14,24.17,24.30$, \\
Technologically advanced manufacturing indus- & $24.42,24.62,24.63,24.64,24.66,29.12,29.13$, \\
tries & $29.14,29.31,29.32,29.40,29.52,29.53,29.54$, \\
& $29.55,29.56,30.01,31.10,31.40,31.50,32.30$, \\
Non-technology oriented manufacturing & $33.10,33.40,34.10,34.30,35.40$ \\
Construction & $15-37$ without high tech and technologically \\
Trade & advanced manufacturing industries \\
Transport and postal services & 45 \\
Credit and insurance & $50,51,52$ \\
Technology oriented services & $60,61,62,63,641$ \\
Non-technology oriented services & $65,66,67$ \\
Knowledge intensive services & $642,72,731,742,743$ \\
& $73.2,74.11,74.12,74.13,74.14,74.4$ \\
Other business oriented services & Technology and non-technology oriented ser- \\
& vices \\
Business oriented services & $71.1,71.2,71.3,74.5,74.6,74.7,74.8$ (without \\
Consumer oriented services & $74.87), 90$ \\
\hline
\end{tabular}

Table A2: Definition of variables

\begin{tabular}{|c|c|}
\hline Variable & Definition \\
\hline Start-up rate & $\begin{array}{l}\text { Number of newly founded firms in the industry }{ }^{a} \text { per } 10,000 \text { re- } \\
\text { gional workforce }{ }^{b} \text {. }\end{array}$ \\
\hline $\begin{array}{l}\text { Unemployment rate - cyclical } \\
\text { component }\end{array}$ & $\begin{array}{l}\text { Number of registered unemployed persons over the entire work- } \\
\text { ing population.c }\end{array}$ \\
\hline GDP - cyclical component & $\begin{array}{l}\text { Nominal GDP divided by the annual consumer price index (CPI) } \\
\text { of the Federal Statistical Office. }{ }^{d}\end{array}$ \\
\hline Employees in small businesses & $\begin{array}{l}\text { Share of employees in establishments with less than } 20 \text { employ- } \\
\text { ees. }{ }^{\text {b }}\end{array}$ \\
\hline $\begin{array}{l}\text { Employees with tertiary educa- } \\
\text { tion }\end{array}$ & Share of employees with a university degree. ${ }^{b}$ \\
\hline Number of professors & $\begin{array}{l}\text { Number of university professors at universities in the region in the } \\
\text { respective year per per } 1,000 \text { workforce. }{ }^{\mathrm{e}}\end{array}$ \\
\hline Patent applications & $\begin{array}{l}\text { Number of patent applications with an inventor residing in the re- } \\
\text { gione per } 1,000 \text { workforce }^{.}\end{array}$ \\
\hline
\end{tabular}

Data Sources: a) ZEW Mannheim Enterprise Panel. b) Establishment History File of the Social Insurance Statistics. c) Federal Employment Agency. d) Federal Statistical Office, Working Committee "Volkswirtschaftliche Gesamtrechnung der Länder". e) German University Statistics, Federal Statistical Office. f) RegPat database. g) Deutsche Bundesbank. 
Table A3: Correlations among variables

\begin{tabular}{l|lccccc}
\hline \multicolumn{2}{l}{} & 1 & 2 & 3 & 4 & 5 \\
\hline 1 & Unemployment rate - cyclical component & 1 & & & & \\
2 & GDP - cyclical component & -0.390 & 1 & & & \\
3 & Employees in small businesses & 0.015 & 0.033 & 1 & & \\
4 & Employees with tertiary education & -0.057 & -0.026 & -0.421 & 1 & \\
5 & Number of professors & -0.003 & 0.013 & -0.398 & 0.338 & 1 \\
6 & Patent applications & -0.179 & 0.092 & -0.382 & 0.101 & -0.003 \\
\hline
\end{tabular}

Table A4: Average annual number over the 1995-2008 period of start-ups per region

\begin{tabular}{|c|c|c|c|c|c|c|c|}
\hline & NUTS2 Region & NUTS2 code & All & Type 1 & Type 2 & Type 3 & Type 4 \\
\hline 1 & Stuttgart & DE11 & 10088 & 6172 & 1010 & 2773 & 133 \\
\hline 2 & Karlsruhe & $\mathrm{DE} 12$ & 7210 & 4560 & 664 & 1896 & 90 \\
\hline 3 & Freiburg & DE13 & 5630 & 3620 & 567 & 1360 & 82 \\
\hline 4 & Tübingen & DE14 & 4691 & 2892 & 491 & 1237 & 71 \\
\hline 5 & Oberbayern & DE21 & 14785 & 8895 & 1139 & 4607 & 143 \\
\hline 6 & Niederbayern & DE22 & 2974 & 2053 & 309 & 582 & 31 \\
\hline 7 & Oberpfalz & DE23 & 2750 & 1827 & 305 & 588 & 30 \\
\hline 8 & Oberfranken & DE24 & 3328 & 2316 & 314 & 667 & 32 \\
\hline 9 & Mittelfranken & DE25 & 4518 & 2866 & 470 & 1133 & 49 \\
\hline 10 & Unterfranken & DE26 & 3430 & 2266 & 335 & 793 & 36 \\
\hline 11 & Schwaben & DE27 & 5093 & 3280 & 493 & 1264 & 55 \\
\hline 12 & Berlin & DE30 & 13598 & 9586 & 782 & 3143 & 86 \\
\hline 13 & Brandenburg & DE40 & 8291 & 5923 & 779 & 1531 & 59 \\
\hline 14 & Bremen & DE50 & 2043 & 1313 & 220 & 494 & 16 \\
\hline 15 & Hamburg & DE60 & 8885 & 5039 & 886 & 2909 & 50 \\
\hline 16 & Darmstadt & DE71 & 12991 & 8118 & 1065 & 3700 & 109 \\
\hline 17 & Gießen & DE72 & 2528 & 1729 & 225 & 546 & 29 \\
\hline 18 & Kassel & DE73 & 2854 & 1962 & 262 & 605 & 25 \\
\hline 19 & Meckl.-Vorpom. & DE80 & 5019 & 3671 & 477 & 837 & 34 \\
\hline 20 & Braunschweig & DE91 & 5536 & 3842 & 398 & 1257 & 39 \\
\hline 21 & Hannover & DE92 & 6558 & 4414 & 575 & 1512 & 56 \\
\hline 22 & Lüneburg & DE93 & 4411 & 3025 & 450 & 898 & 38 \\
\hline 23 & Weser-Ems & DE94 & 6545 & 4476 & 811 & 1205 & 52 \\
\hline 24 & Düsseldorf & DEA1 & 15884 & 10608 & 1363 & 3758 & 155 \\
\hline 25 & Köln & DEA2 & 12435 & 8130 & 971 & 3232 & 101 \\
\hline 26 & Münster & DEA3 & 6152 & 4325 & 523 & 1248 & 55 \\
\hline 27 & Detmold & DEA4 & 5602 & 3839 & 590 & 1109 & 65 \\
\hline 28 & Arnsberg & DEA5 & 9327 & 6449 & 843 & 1931 & 104 \\
\hline 29 & Koblenz & DEB1 & 4291 & 2943 & 409 & 902 & 37 \\
\hline 30 & Trier & DEB2 & 950 & 676 & 99 & 169 & 7 \\
\hline 31 & Rheinh.-Pfalz & DEB3 & 6381 & 4386 & 530 & 1416 & 49 \\
\hline 32 & Saarland & DECO & 2389 & 1631 & 217 & 517 & 24 \\
\hline 33 & Dresden & DED2 & 4792 & 3238 & 435 & 1069 & 51 \\
\hline 34 & Chemnitz & DED4 & 4388 & 3135 & 432 & 770 & 51 \\
\hline 35 & Leipzig & DED5 & 3172 & 2216 & 232 & 702 & 21 \\
\hline 36 & Sachsen-Anhalt & DEEO & 6413 & 4562 & 615 & 1183 & 53 \\
\hline 37 & Schles.-Holstein & DEFO & 8526 & 5837 & 842 & 1764 & 82 \\
\hline 38 & Thüringen & DEGO & 6603 & 4604 & 693 & 1223 & 84 \\
\hline
\end{tabular}


Table A5: Correlation between start-up rates in different industries

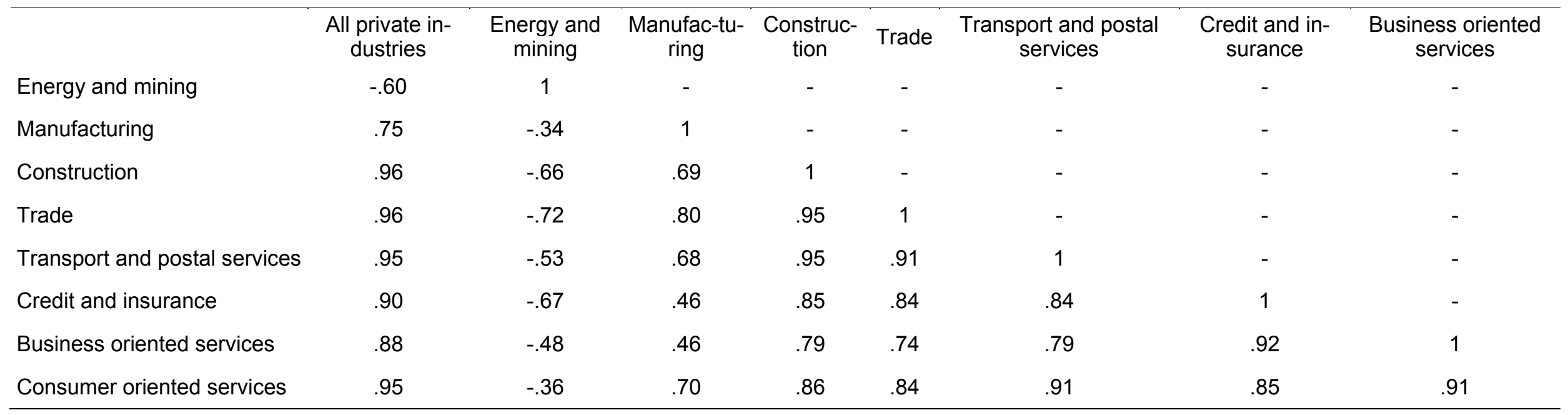


Table A6: Correlation between start-up rates in predominantly innovative industries

\begin{tabular}{lcccccc}
\hline & $\begin{array}{c}\text { All private } \\
\text { industries }\end{array}$ & $\begin{array}{c}\text { Innovative } \\
\text { manufacturing }\end{array}$ & $\begin{array}{c}\text { High tech } \\
\text { manufacturing }\end{array}$ & $\begin{array}{c}\text { Technologically ad- } \\
\text { vanced manufacturing }\end{array}$ & $\begin{array}{c}\text { Non-innovative } \\
\text { manufacturing }\end{array}$ & $\begin{array}{c}\text { Knowledge intensive } \\
\text { services }\end{array}$ \\
$\begin{array}{l}\text { Innovative manufactur- } \\
\text { ing }\end{array}$ & .76 & 1 & - & - & - & - \\
$\begin{array}{l}\text { High tech manufactur- } \\
\text { ing }\end{array}$ & .78 & .98 & 1 & - & - & - \\
$\begin{array}{l}\text { Technologically ad- } \\
\text { vanced manufacturing }\end{array}$ & .74 & .99 & .96 & 1 & - & - \\
$\begin{array}{l}\text { Non-innovative manu- } \\
\text { facturing }\end{array}$ & .68 & .72 & 0.75 & 0.69 & 1 & - \\
$\begin{array}{l}\text { Knowledge intensive } \\
\text { services }\end{array}$ & .93 & .74 & .76 & .72 & 0.59 & 1 \\
$\begin{array}{l}\text { Technology-oriented } \\
\text { services }\end{array}$ & .88 & .81 & .84 & .79 & 0.60 & .98 \\
\hline
\end{tabular}


Table A7: Influence of cyclical variables on start-ups conditional on the four types with professor growth dummy

\begin{tabular}{lllll}
\hline & $\begin{array}{l}\text { Type 1: } \\
\text { non-innova- } \\
\text { tive and } \\
\text { small }\end{array}$ & $\begin{array}{l}\text { Type 2: } \\
\text { non-innova- } \\
\text { tive and large }\end{array}$ & $\begin{array}{l}\text { Type 3: } \\
\text { innovative }\end{array}$ & $\begin{array}{l}\text { Type 4: } \\
\text { innovative } \\
\text { and large }\end{array}$ \\
\hline $\begin{array}{l}\text { Unemployment rate }- \text { cyclical } \\
\text { component } t-1\end{array}$ & $0.07^{* *}$ & $0.10^{* * *}$ & -0.01 & $0.09^{* * *}$ \\
$\begin{array}{l}\text { GDP }- \text { cyclical component } \\
t-1\end{array}$ & $-0.18^{* * *}$ & -0.03 & $-0.16^{* * *}$ & -0.09 \\
\hline $\begin{array}{l}\text { Share of employees in small } \\
\text { businesses } t-1 \text { (growth) }\end{array}$ & -0.00 & -0.05 & $0.10^{* * *}$ & $0.13^{* * *}$ \\
$\begin{array}{l}\text { Share of employees with ter- } \\
\text { tiary education } t-1 \text { (growth) }\end{array}$ & $-0.12^{* *}$ & 0.01 & $-0.07^{* *}$ & -0.02 \\
$\begin{array}{l}\text { High professor growth } t-1 \\
\text { Number of patent applica- } \\
\text { tions per 1,000 workforce } t-\end{array}$ & $1.60^{* * *}$ & $0.27^{* * *}$ & $3.42^{* * *}$ & -0.09 \\
$\begin{array}{l}\text { (growth) } \\
\text { Constant }\end{array}$ & $0.13^{* * *}$ & 0.01 & $0.07^{* * *}$ & $0.16^{* * *}$ \\
$\mathrm{R}^{2}$ & $-0.62^{* * *}$ & $-0.21^{* * *}$ & $0.36^{* * *}$ & $0.67^{* * *}$ \\
\hline
\end{tabular}

Notes: Notes: Fixed effects panel estimates. ${ }^{* * *},{ }^{* *}$ statistically significant at the 1 percent and the 5 percent level, respectively. Business cycle is the cyclical component of the Hodrick-Prescott filtered variables. The remaining independent variables besides dummies are included in growth rates. All variables are lagged by one period. The number of observations is 494 ( 38 cross sections, 13 years) in all models. Standard errors are clustered at the region level.

Table A8: First stage for unemployment cycle, where unemployment is the dependent variable

\begin{tabular}{ll}
2004 labor market reform & $0.61^{* * *}$ \\
\hline Share of employees in small businesses $t-1$ & $-0.27^{* * *}$ \\
Share of employees with tertiary education $t-1$ & $-0.20^{\star * *}$ \\
Number of professors per 1,000 workforce $t-1$ & -0.04 \\
Number of patent applications per 1,000 workforce $t-1$ & $0.30^{\star * *}$ \\
Constant & -0.05
\end{tabular}

Notes: Fixed effects panel estimates. ${ }^{* * *},{ }^{* *}$ statistically significant at the 1 percent and the 5 percent level, respectively. Business cycle is the cyclical component of the Hodrick-Prescott filtered variables. Besides the instrument, the remaining independent variables are included in growth rates. All variables besides the instrument are lagged by one period, including the dependent variable. The number of observations is 494 (38 cross sections, 13 years) in all models. Standard errors are clustered at the region level. 
Table A9: First stage for GDP cycle, where GDP is the dependent variable

2007 pre-crisis boom

$1.29^{* * *}$

\begin{tabular}{ll}
\hline Share of employees in small businesses $t-1$ & $0.24^{\star * *}$ \\
Share of employees with tertiary education $t-1$ & 0.04 \\
Number of professors per 1,000 workforce $t-1$ & 0.04 \\
Number of patent applications per 1,000 workforce $t-1$ & $-0.15^{\text {} t *}$ \\
Constant & $0.13^{\text {***}}$
\end{tabular}

Notes: Fixed effects panel estimates. ${ }^{* * *},{ }^{* *}$ statistically significant at 1 percent and 5 percent, respectively. Business cycle is the cyclical component of the Hodrick-Prescott filtered variables. Besides the instrument, the remaining independent variables are included in growth rates. All variables besides the instrument are lagged by one period, including the dependent variable. The number of observations is 494 (38 cross sections, 13 years) in all models. Standard errors are clustered at the region level.

Table A10: Influence of the GDP cycle on start-ups conditional on size given that the GDP cycle is instrumented by the 2007 pre-crisis peak

\begin{tabular}{lll}
\hline Start-up rates in: & $\begin{array}{l}\text { Type 1+3 without } \\
\text { banking: small size in- } \\
\text { dustries }\end{array}$ & $\begin{array}{l}\text { Type 2+4: } \\
\text { large size industries }\end{array}$ \\
\hline $\begin{array}{l}\text { GDP - cyclical component } t-1 \text { (instrumented by } \\
\text { pre-crisis boom) }\end{array}$ & $-0.36^{* * *}$ & -0.09 \\
\hline Share of employees in small businesses $t-1$ & $0.06^{* *}$ & -0.05 \\
$\begin{array}{l}\text { Share of employees with tertiary education } t-1 \\
\text { Number of professors per 1,000 workforce } t-1\end{array}$ & -0.03 & -0.01 \\
$\begin{array}{l}\text { Number of patent applications per 1,000 workforce } \\
t-1\end{array}$ & 0.02 & 0.02 \\
$\begin{array}{l}\text { Entries into credit and insurance } t-1 \text { (proxy for } \\
\text { "health" of finance industry) }\end{array}$ & $0.33^{* * *}$ & 0.05 \\
Constant & $-0.22^{* * *}$ & 0.04 \\
\hline
\end{tabular}

Notes: Instrumental variables estimations with fixed effects. ${ }^{* * *},{ }^{* *}$ statistically significant at 1 percent and 5 percent, respectively. Business cycle is the cyclical component of the Hodrick-Prescott filtered variables. The remaining independent variables are included in growth rates. All variables are lagged by one period. The number of observations is 494 (38 cross sections, 13 years) in all models. Standard errors are clustered at the region level. 
Table A11: Influence of cyclical variables on start-ups conditional on the four types using Hodrick-Prescott and Baxter-King filter in the same data set

\begin{tabular}{|c|c|c|c|c|c|c|c|c|}
\hline \multirow[t]{2}{*}{ Start-up rates in: } & \multicolumn{2}{|c|}{$\begin{array}{c}\text { Type 1: } \\
\text { non-innovative } \\
\text { and small }\end{array}$} & \multicolumn{2}{|c|}{$\begin{array}{l}\text { Type 2: } \\
\text { non-innovative } \\
\text { and large }\end{array}$} & \multicolumn{2}{|c|}{$\begin{array}{l}\text { Type 3: } \\
\text { innovative and } \\
\text { small }\end{array}$} & \multicolumn{2}{|c|}{$\begin{array}{l}\text { Type 4: } \\
\text { innovative and } \\
\text { large }\end{array}$} \\
\hline & $\mathrm{HP}$ & BK & HP & BK & HP & BK & HP & BK \\
\hline $\begin{array}{l}\text { Unemployment rate - cycli- } \\
\text { cal component } t-1\end{array}$ & $0.05^{\star *}$ & $0.06^{* * *}$ & $0.11^{* * *}$ & $0.10^{* * *}$ & -0.03 & -0.03 & -0.02 & -0.01 \\
\hline $\begin{array}{l}\text { GDP - cyclical component } \\
t-1\end{array}$ & $-0.18^{* * *}$ & $-0.17^{* * *}$ & -0.01 & -0.02 & $-0.19^{\star * *}$ & $-0.20^{\star * *}$ & -0.05 & -0.05 \\
\hline $\begin{array}{l}\text { Share of employees in } \\
\text { small businesses } t-1\end{array}$ & -0.05 & -0.06 & $-0.09^{* * *}$ & $-0.10^{* * *}$ & $0.12^{* * *}$ & $0.11^{* * *}$ & $0.15^{* * *}$ & $0.15^{* * *}$ \\
\hline $\begin{array}{l}\text { Share of employees with } \\
\text { tertiary education } t-1\end{array}$ & $-0.10^{* *}$ & $-0.10^{* *}$ & 0.04 & 0.03 & $-0.05^{\star *}$ & $-0.05^{\star *}$ & $-0.12^{\star \star *}$ & $-0.12^{* *}$ \\
\hline $\begin{array}{l}\text { Number of professors per } \\
1,000 \text { workforce } t-1\end{array}$ & 0.02 & 0.02 & 0.02 & 0.02 & 0.02 & 0.03 & 0.01 & 0.02 \\
\hline $\begin{array}{l}\text { Number of patent applica- } \\
\text { tions per } 1,000 \text { workforce } \\
t-1\end{array}$ & 0.04 & 0.05 & -0.03 & -0.03 & $0.06^{* * *}$ & $0.06^{* * *}$ & $0.10^{* *}$ & $0.10^{\star *}$ \\
\hline Constant & $-0.65^{* * *}$ & $-0.64^{* \star *}$ & $-0.24^{* \star *}$ & $-0.23^{\star * *}$ & $0.32^{* * *}$ & $0.33^{* * *}$ & $0.52^{* * *}$ & $0.52^{* \star *}$ \\
\hline $\mathrm{R}^{2}$ & 0.63 & 0.62 & 0.76 & 0.76 & 0.70 & 0.70 & 0.46 & 0.46 \\
\hline
\end{tabular}

Notes: Fixed effects panel estimates. ${ }^{* * *},{ }^{* *}$ statistically significant at the 1 percent and the 5 percent level, respectively. Business cycle is the cyclical component of the Hodrick-Prescott filtered (HP) or Baxter-King filtered (BK) variables, where the same observations are used in the estimation procedure. The remaining independent variables are included in growth rates. All variables are lagged by one period. The number of observations is 411 (due to filtering values at the beginning and the end of a time series are lost) in all models. 
Figure A1: Bi-regional correlations between GDP and unemployment cycle

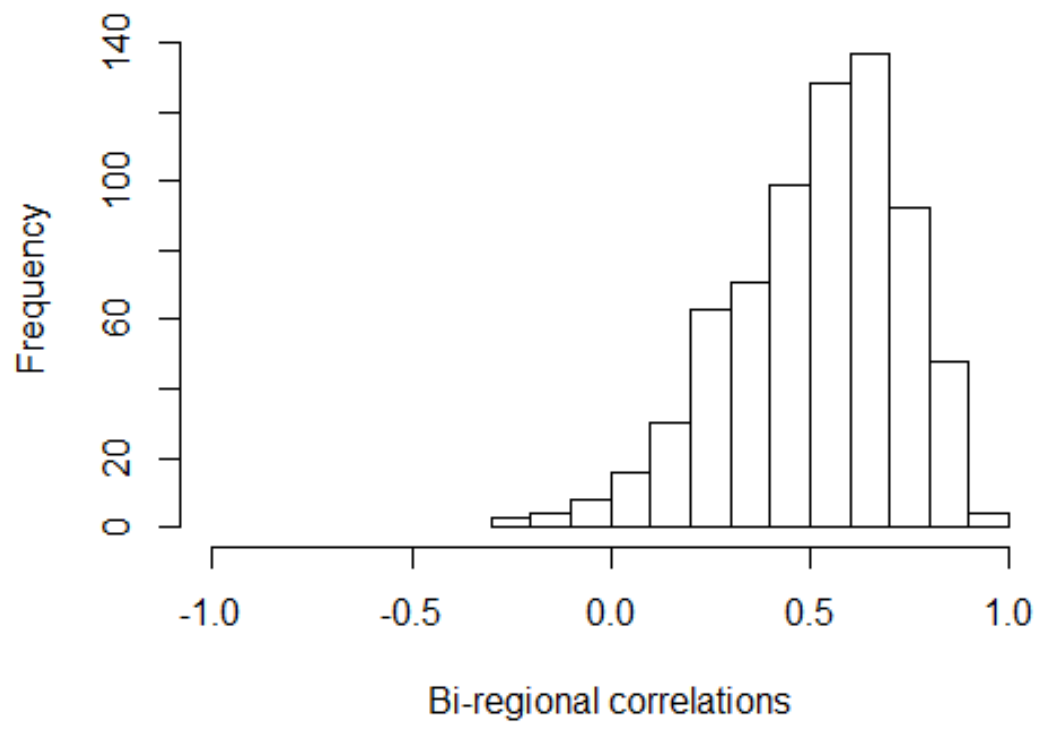

(a) GDP cycle

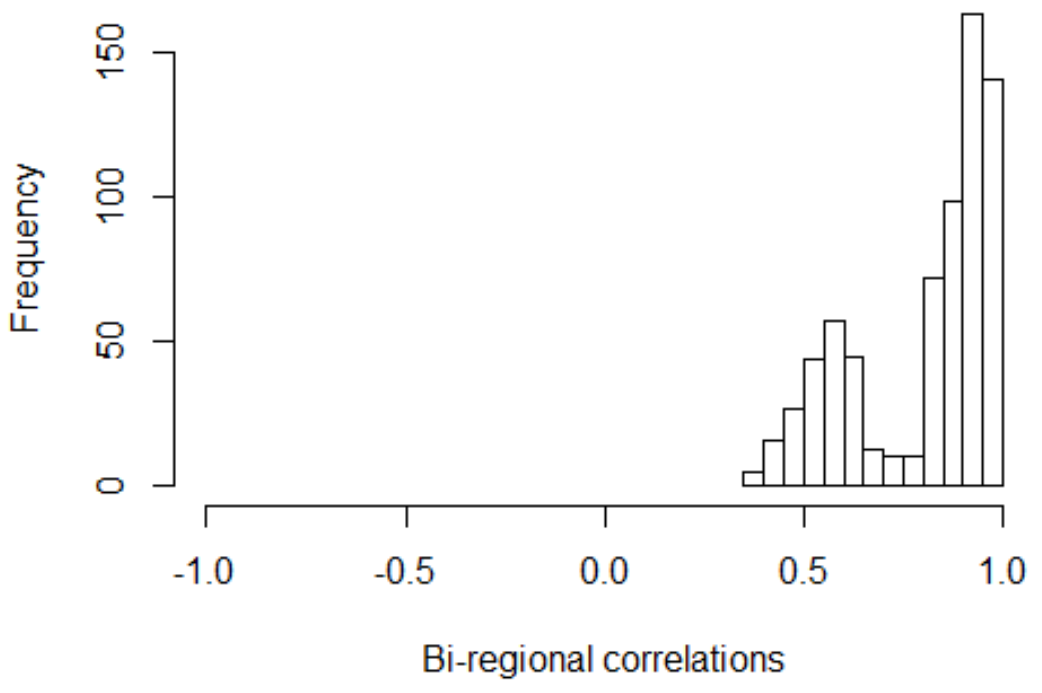

(b) Unemployment cycle 


\section{Appendix B: spatial error model}

To test whether our results are sensitive to including unobserved spatial dependencies, we estimate the following spatial error model with spatial fixed effects:

Startup rate ${ }_{i, t}^{\tau}=\mu_{i}^{\tau}+\alpha_{1}^{\tau} \mathrm{BC}$ unemployment ${ }_{i, t-1}+\alpha_{2}^{\tau} \mathrm{BC} \mathrm{GDP}_{i, t-1}+\boldsymbol{\eta}_{\tau}^{\top} \mathbf{x}_{i, t-1}+s u_{i, t}^{\tau}$ (B1) The main difference between the model in (6) and (B1) is that instead of a simple error term $u_{i, t}^{\tau}$, we now have a spatially lagged error $s u_{i, t}^{\tau}$. Suppressing the type indicator for notational convenience, the spatial error is constructed as follows:

$$
s u_{i, \mathrm{t}}=\zeta \sum_{j=1}^{\mathrm{N}} \mathrm{w}_{i, j} s u_{j, t}+\varepsilon_{i, t}
$$

where $\zeta \in(0,1)$. Thus, the effect in region $i$ depends on the weighted effects from all other regions $\sum_{j=1}^{\mathrm{N}} \mathrm{w}_{i, j} s u_{j, t}$ and a region-specific effect $\varepsilon_{i, t}$. The weights are constructed in two steps. In the first step, two regions with a common border are assigned a weight of 1 such that

$$
\widetilde{\mathrm{w}}_{i, j}=\left\{\begin{array}{l}
1 \text { if } i \text { and } j \text { have a common border } \\
0 \text { if no common border or if } i=j
\end{array}\right.
$$

while regions without a common border are assigned a weight of 0 . In the second step, weights are normalized such that they sum up to $1: \mathrm{w}_{i, j}=\widetilde{\mathrm{w}}_{i, j}\left(\sum_{i=1}^{\mathrm{N}} \widetilde{\mathrm{w}}_{i, j}\right)^{-1}$. The model in (B1) is estimated with maximum likelihood, as suggested by Elhorst (2003).

Table B1: Influence of cyclical variables on start-ups with spatially lagged errors

\begin{tabular}{lcccc}
\hline Start-up rates in: & $\begin{array}{c}\text { Type 1: } \\
\text { non-innovative } \\
\text { and small }\end{array}$ & $\begin{array}{c}\text { Type 2: } \\
\text { non-innovative } \\
\text { and large }\end{array}$ & $\begin{array}{c}\text { Type 3: } \\
\text { innovative and } \\
\text { small }\end{array}$ & $\begin{array}{c}\text { Type 4: } \\
\text { innovative and } \\
\text { large }\end{array}$ \\
\hline $\begin{array}{l}\text { Unemployment rate }- \text { cyclical } \\
\text { component } t-1\end{array}$ & 0.05 & $0.08^{* *}$ & 0.01 & $0.09^{* *}$ \\
GDP - cyclical component $t-1$ & $-0.07^{* *}$ & -0.05 & $-0.10^{* * *}$ & -0.01 \\
\hline $\begin{array}{l}\text { Share of employees in small busi- } \\
\text { nesses } t-1\end{array}$ & -0.02 & -0.03 & 0.03 & $0.09^{* *}$ \\
$\begin{array}{l}\text { Share of employees with tertiary } \\
\text { education } t-1\end{array}$ & 0.00 & 0.01 & -0.01 & -0.04 \\
$\begin{array}{l}\text { Number of professors per } 1,000 \\
\text { workforce } t-1\end{array}$ & -0.01 & 0.02 & 0.01 & 0.02 \\
$\begin{array}{l}\text { Number of patent applications per } \\
1,000 \text { workforce } t-1\end{array}$ & 0.03 & 0.01 & 0.04 & $0.09^{* * *}$ \\
Spatial error coefficient $(\zeta)$ & $0.67^{* * *}$ & $0.46^{* * *}$ & $0.44^{* * *}$ & $0.49^{* * *}$ \\
\hline
\end{tabular}

Notes: ${ }^{* * *},{ }^{* *}$ statistically significant at 1 percent and 5 percent, respectively; fixed effects estimation with spatial errors; business cycle is the cyclical component of the Hodrick-Prescott filtered variables. The remaining independent variables are included in growth rates. All variables are lagged by one period. The number of observations is 494 ( 38 cross sections, 13 years) in all models. 


\section{Appendix C: Steady state in the matching model}

The model is a standard matching model and the steady state can be easily determined. It is easy to show that the number of potential entrepreneurs in wage work develops according to $\dot{v}(t)=\sigma-[\theta(t)+\sigma] \vartheta(t)$. Using the steady state condition $\dot{v}(t)=$ 0 , we obtain

$$
v^{*}=\frac{\sigma}{\theta^{*}+\sigma}
$$

where values with an asterisk are steady-state values. To fully specify the steady-state number of entrepreneurs, we must determine $\theta^{*}$ in (C1). Let $\eta_{+}$denote the steady-state asset value of matching and $\eta_{-}$the steady-state asset value of not matching. The discounted value of a match for an investor is $\delta \eta_{+}^{i}=y-\gamma(1-\vartheta) w(y)-\pi+\sigma\left[\eta_{-}^{i}-\eta_{+}^{i}\right]$ and the discounted value of not matching is $\delta \eta_{-}^{i}=\beta(1-\vartheta) w(y)+\theta^{*}\left[\eta_{+}^{i}-\eta_{-}^{i}\right]$. However, only $\eta_{-}^{i}=0$ is consistent with free entry of investors, such that we obtain $\eta_{+}^{i}=c\left(\phi^{*}\right)^{-1}=$ $(y-\gamma[1-\vartheta] w(y)-\pi)(\delta+\sigma)^{-1}$. The discounted asset value of a match for potential entrepreneurs is $\delta \eta_{+}^{\ell}=\pi+\sigma\left(\eta_{-}^{\ell}-\eta_{+}^{\ell}\right)$ and the discounted asset value of not matching is $\delta \eta_{-}^{\ell}=\beta(1-\vartheta) w(y)+\theta^{*}\left(\eta_{+}^{\ell}-\eta_{-}^{\ell}\right)$. Solving the linear system given by $\delta \eta_{+}^{\ell}$ and $\delta \eta_{-}^{\ell}$, yields $\eta_{+}^{\ell}=\left(\beta[1-\vartheta] \sigma w(y)+\left[\theta^{*}+\delta\right] \pi\right)\left(\delta\left[\theta^{*}+\delta+\sigma\right]\right)^{-1}$, respectively $\eta_{-}^{\ell}=(\beta[1-\vartheta] \sigma w(y)+$ $\left.\beta[1-\vartheta] \delta w(y)+\theta^{*} \pi\right)\left(\delta\left[\theta^{*}+\delta+\sigma\right]\right)^{-1}$.

Investors will accept a match if $\eta_{+}^{i}>\eta_{-}^{i}=0$ and potential entrepreneurs will accept a match if $\eta_{+}^{\ell}>\eta_{-}^{\ell}$ resulting in the following conditions for entrepreneurial income: (R1) $y-\gamma(1-\vartheta) w(y)>\beta(1-\vartheta) w(y)$ such that a contract, acceptable to both sides, exists and (R2) $\pi \in\{\pi: \beta(1-\vartheta) w(y)<\pi<y-\gamma(1-\vartheta) w(y)\}$ such that both parties agree. We assume that the income contract realized depends on the bargaining power of potential entrepreneurs $\rho \in(0,1)$ :

$$
\pi=[1-\rho] \beta(1-\vartheta) w(y)+\rho[y-\gamma(1-\vartheta) w(y)]
$$

By plugging $\pi$ in (C2) into $\eta_{+}^{i}$ and using $\lambda^{*}=\left(\phi^{*}\right)^{-\frac{1}{\varepsilon}}$, we obtain $\lambda^{*}$. Using $\theta^{*}=$ $\left(\lambda^{*}\right)^{1-\varepsilon}$, we get

$$
\theta^{*}=(1-\rho)^{\frac{1-\varepsilon}{\varepsilon}}\left[\frac{y-(\gamma+\beta)(1-\vartheta) w(y)}{c[\delta+\sigma]}\right]^{\frac{1-\varepsilon}{\varepsilon}}
$$


Consequently, using $e^{*}=1-v^{*},(\mathrm{C} 1)$, and (C3), ${ }^{32}$ the steady-state number of entrepreneurs is

$$
e^{*}= \begin{cases}\frac{\theta^{*}}{\sigma+\theta^{*}}, & \text { if } y>(\gamma+\beta)(1-\vartheta) w(y) \\ 0, & \text { else }\end{cases}
$$

Last, we assume that entrepreneurs have a sufficiently high productivity level, $y>$ $(\gamma+\beta)(1-\vartheta) w(y)$, such that the steady-state number of entrepreneurs is strictly positive.

32 The steady-state matching rate of investors and entrepreneurs, as well as the steady-state number of entrepreneurs, either holds for potential necessity entrepreneurs, if $\beta=1$, or opportunity entrepreneurs, if $\beta=(1-\vartheta)^{-1}$. Furthermore, we can also differentiate between the steady-state value for businesses mostly driven by entrepreneurial labor, if $\gamma=0$, and businesses employing a potentially large number of workers, if $\gamma>0$. 